\title{
SYSTEMATIC REVISION OF THE VIZCACHAS (RODENTIA, CAVIOMORPHA, CHINCHILLIDAE) FROM THE CHAPADMALAL FORMATION, LATE PLIOCENE OF BUENOS AIRES PROVINCE, ARGENTINA
}

\author{
LUCIANO LUIS RASIA AND ADRIANA M. CANDELA
}

1'División Paleontología Vertebrados, Museo de La Plata, Paseo del Bosque s/n, B1900FWA La Plata, Argentina. CONICET.

lucianorasia@conicet.gov.ar, acandela@museo.fcnym.unlp.edu.ar

\begin{abstract}
Lagostomine rodents (Caviomorpha, Chinchillidae) are very abundant in late Cenozoic vertebrate associations of the Pampean area but the study of their systematics has been mostly limited to a handful of works from the late $19^{\text {th }}$ Century and early $20^{\text {th }}$ Century. Although seven species of Lagostomus were described for the Chapadmalal Formation (late Pliocene; Buenos Aires Province, Argentina), the holotypes of these species do not present precise stratigraphic provenance and have not been studied since their original description. This study of lagostomines from the Chapadmalal Formation with precise stratigraphic provenance gives way to the recognition of at least three species: Lagostomus incisus, L. compressidens and L. euplasius. The comparative study of the holotypes of the previously recognized species in this unit indicates that 'Viscaccia indefinita' is a junior synonym of $L$. compressidens while ' $V$. loberiaense', ' $V$. definita' and ' $V$. chapalmalense' are junior synonyms of $L$. euplasius. The validity of 'Viscaccia arcuata' and its inclusion in the Chapadmalalan fauna has to be re-evaluated. This work clarifies part of the systematics of the genus Lagostomus, thus contributing to the comprehension of the taxonomic diversity of chinchillids during their most recent evolutionary history.
\end{abstract}

Key words. Late Pliocene. Rodentia. Caviomorpha. Chinchillidae. Systematics. Buenos Aires. Argentina.

Resumen. REVISIÓN SISTEMÁTICA DE LAS VIZCACHAS (RODENTIA, CAVIOMORPHA, CHINCHILLIDAE) DE LA FORMACIÓN CHAPADMALAL, PLIOCENO TARDÍO DE LA PROVINCIA DE BUENOS AIRES, ARGENTINA. Los roedores lagostominos (Caviomorpha, Chinchillidae) son muy abundantes en las asociaciones de vertebrados en el Cenozoico tardío del área pampeana, pero su estudio sistemático se limita mayormente a algunos trabajos de fines del Siglo XIX y principios del Siglo XX. Se describieron siete especies de Lagostomus para la Formación Chapadmalal (Plioceno tardío; provincia de Buenos Aires, Argentina), pero los holotipos de estas especies no tienen procedencia estratigráfica precisa y no han sido estudiados desde su descripción original. Este estudio de lagostominos de la Formación Chapadmalal con procedencia estratigráfica precisa permitió reconocer al menos tres especies: Lagostomus incisus, L. compressidens y L. euplasius. El análisis comparativo de los holotipos de las especies previamente reconocidas en esta unidad indica que 'Viscaccia indefinita' es un sinónimo junior de L. compressidens; y que 'V. Ioberiaense', 'V. definita' y 'V. chapalmalense' son sinónimos junior de L. euplasius. La validez de 'Viscaccia arcuata' y su inclusión en la fauna Chapadmalalense debe ser re-evaluada. Este trabajo permite esclarecer parte de la sistemática del género Lagostomus, contribuyendo así a la comprensión de la diversidad taxonómica de los chinchílidos durante su historia evolutiva más reciente.

Palabras clave. Plioceno tardío. Rodentia. Caviomorpha. Chinchillidae. Sistemática. Buenos Aires. Argentina.

THE plains vizcacha, Lagostomus maximus, is the only living representative of the subfamily Lagostominae, a group of caviomorph rodents which, together with the subfamily Chinchillinae, is included in the Chinchillidae (e.g., Pocock, 1922). Vizcachas inhabit a wide variety of lowland habitats, including the pampas and adjoining semiarid Monte and Chaquenean regions of Argentina, southern Bolivia and Paraguay (Jackson, et al., 1996; Ojeda and Bidau, 2013). They are sexually dimorphic, gregarious and nocturnal, and build complex burrow systems called 'vizcacheras' (Weir, 1974).

The subfamily Chinchillinae is poorly represented in the fossil record and its oldest representative is an undetermined chinchilline from the early Miocene of Chile (Flynn et al., 2002). Additionally, there are records of the living genus Lagidium from the Pleistocene of Peru (Marshall et al., 1984; Walton, 1997) and late Holocene of Argentina (Ortiz et al., 2012) as well as those of the living species Chinchilla chin- 
chilla in the late Holocene of Argentina (Ortiz et al., 2012).

The oldest known Chinchillidae is Eoviscaccia (traditionally considered a lagostomine; Vucetich, 1989), from the early Oligocene (Tinguirirican) of Chile (Flynn et al., 2003; Bertrand et al., 2012), the late Oligocene (Deseadan) of Argentina and Bolivia (Vucetich, 1989, 1991; Bond et al., 1998) and the early Miocene (Colhuehuapian) of Argentina (e.g., Kramarz, 2001; Kramarz et al., 2005). The nature of the relationship between Eoviscaccia and the remaining Chinchillidae is unclear (see Kramarz et al., 2013). Moreover, two Chinchilloidea with possible affinities with Eoviscaccia were recently described (Kramarz et al., 2013; Vucetich et al., 2015) and could represent taxa closely related to the early radiation of Chinchillidae. A more comprehensive analysis of Chinchilloidea is necessary in order to test the phylogenetic position of these basal taxa.

Two undoubted lagostomines are recognized in the early Miocene-middle Miocene ('Pinturan'-Colloncuran): Prolagostomus from Argentina, Bolivia and Chile (e.g., Ameghino, 1887, 1889; Scott, 1905; Vucetich, 1984; Flynn et al., 2008; Croft et al., 2009, 2011), and Pliolagostomus from Argentina (Ameghino, 1887; Vucetich, 1984).

Lagostomines recorded from the late Miocene to Recent were traditionally included in the genus Lagostomus (see Francis and Mones, 1965, 1966, 1968). Besides, two subgenera were recognized: Lagostomopsis, from the late Miocene to late Pliocene, and Lagostomus, from the late Pliocene to Holocene (e.g., Kraglievich, 1926; Vucetich and Verzi, 1995; Cione and Tonni, 2001; Cione et al., 2000; Candela, 2005). Nevertheless, some authors consider Lagostomus and Lagostomopsis separate genera (e.g., Kraglievich, 1934; Pascual, 1966).

Lagostomines are very frequent in vertebrate continental associations from the late Miocene-Holocene in the Pampean area (e.g., Bondesio et al., 1980; Vucetich, 1986; Vucetich and Verzi, 1995; Cione and Tonni, 1999). Nevertheless, little attention has been placed upon the systematics of the Lagostominae at the species level since the contributions of Ameghino (1883, 1886, 1888, 1889, 1891,1908 ) and Rovereto (1914). Perhaps it is for this reason that their inclusion in biostratigraphic studies has only been at a supraspecific level (e.g., Kraglievich, 1934; Cione and Tonni, 1999).

Ameghino (1908) described seven lagostomine species from 'Piso Chapalmalense' (sensu Ameghino, 1908; see below) which he included in the genus 'Viscaccia' (a junior synonym of Lagostomus; see Jackson et al., 1996): Viscaccia euplasia, V. compressidens, V. definita, V. indefinita, V. loberiaense, V. arcuata and V. chapalmalense. The species described for 'Piso Chapalmalense' (Ameghino, 1908) do not boast precise stratigraphic or geographic provenance, Lagostomus incisus being the only confirmed species for the Chapadmalal Formation (sensu Kraglievich, 1952; see Rasia and Candela, 2013).

In the present work, numerous unpublished specimens of chinchillids from the Chapadmalal Formation (Upper Chapadmalalan Stage/Age, late Pliocene; e.g., Cione and Tonni, 2001) with accurate geographic and stratigraphic provenance were studied and compared with the holotypes of the species previously described for 'Piso Chapalmalense', other fossil species of Lagostomus and with the living L. maximus. A new taxonomic proposal for the Chapadmalalan vizcachas is hereby provided on such basis. This systematic study will favor a better comprehension of fossil lagostomines from an evolutionary and biostratigraphic perspective.

\section{MATERIAL AND METHODS}

Lagostomine remains recovered from the Chapadmalal Formation (see Systematic Paleontology for precise stratigraphic provenance of each specimen), from the Atlantic coastal area between Punta Mogotes (near Mar del Plata) and Punta Hermengo (near Miramar) in Buenos Aires Province, Argentina (Fig. 1), were studied. Such material was compared with the available holotypes of the previously recognized species for 'Piso Chapalmalense' (see Ameghino, 1908); that is, 'Viscaccia compressidens', ' $V$. indefinita', ' $V$. definita', 'V. euplasia', 'V. chapalmalense' and 'V. loberiaense'. The holotype of ' $V$. arcuata' could not be found. Comparisons with holotypes and referred material of Lagostomus species from other stratigraphic units, i.e. L. pretrichodactyla (including ' $V$. angulata' and 'V. insolita'; see Marshall and Patterson, 1981), L. antiquus, L. laminosus, L. debilis, L. minimus, L. heterogenidens, L. cavifrons, L. egenus and Lagostomus maximus, were also established (see Appendix 1).

'Lagostomus pallidens', from the late Miocene of Entre Ríos Province, is considered nomen vanum (see Nasif et al., 2013; Rasia, 2016).

Nominal species originally referred to as 'Viscaccia' -a 
junior synonym of Lagostomus, see Jackson et al. (1996)are mentioned between quotation marks. Invalid species (i.e., synonyms, nomina dubia and nomina vana) are also referred to between quotation marks.

Institutional abbreviations. MACN-A, Colección Nacional Ameghino, Museo Argentino de Ciencias Naturales "Bernardino Rivadavia", Buenos Aires; MACN-Ma, Mastozoología, Museo Argentino de Ciencias Naturales "Bernardino Rivadavia", Buenos Aires; MACN-Pv, Colección Nacional Paleovertebrados, Museo Argentino de Ciencias Naturales "Bernardino Rivadavia", Buenos Aires; MASP, Museo Provincial "Antonio Serrano" de Paraná, Paraná; MLP-Mz, Mastozoología, Museo de La Plata, La Plata; MLP-Pv, Paleontología Vertebrados, Museo de La Plata, La Plata.

Quantitative analysis. We used two linear measurements for the upper (P4-M3) and lower (p4-m3) cheek teeth: the anteroposterior diameter (APD) and the transverse diameter (TD) (see Supplementary Material). Linear measurements were log-transformed and analyzed by means of a principal components analysis (PCA) based on a correlation matrix. Analyses were performed using the free access program Past 3.07 (Hammer et al., 2001). Missing data were replaced by iterative imputation (see Ilin and Raiko, 2010) using Past 3.07. Because of the fact that most of the specimens of maxillary fragments and mandibles are not associated, for upper and lower dentition, separate analyses were performed. To evaluate whether PC1 and PC2 of upper and lower cheek teeth proved significantly different among the species from the Chapadmalal Formation, KruskallWallis tests (non-parametric ANOVA) were performed via PAST 3.07.

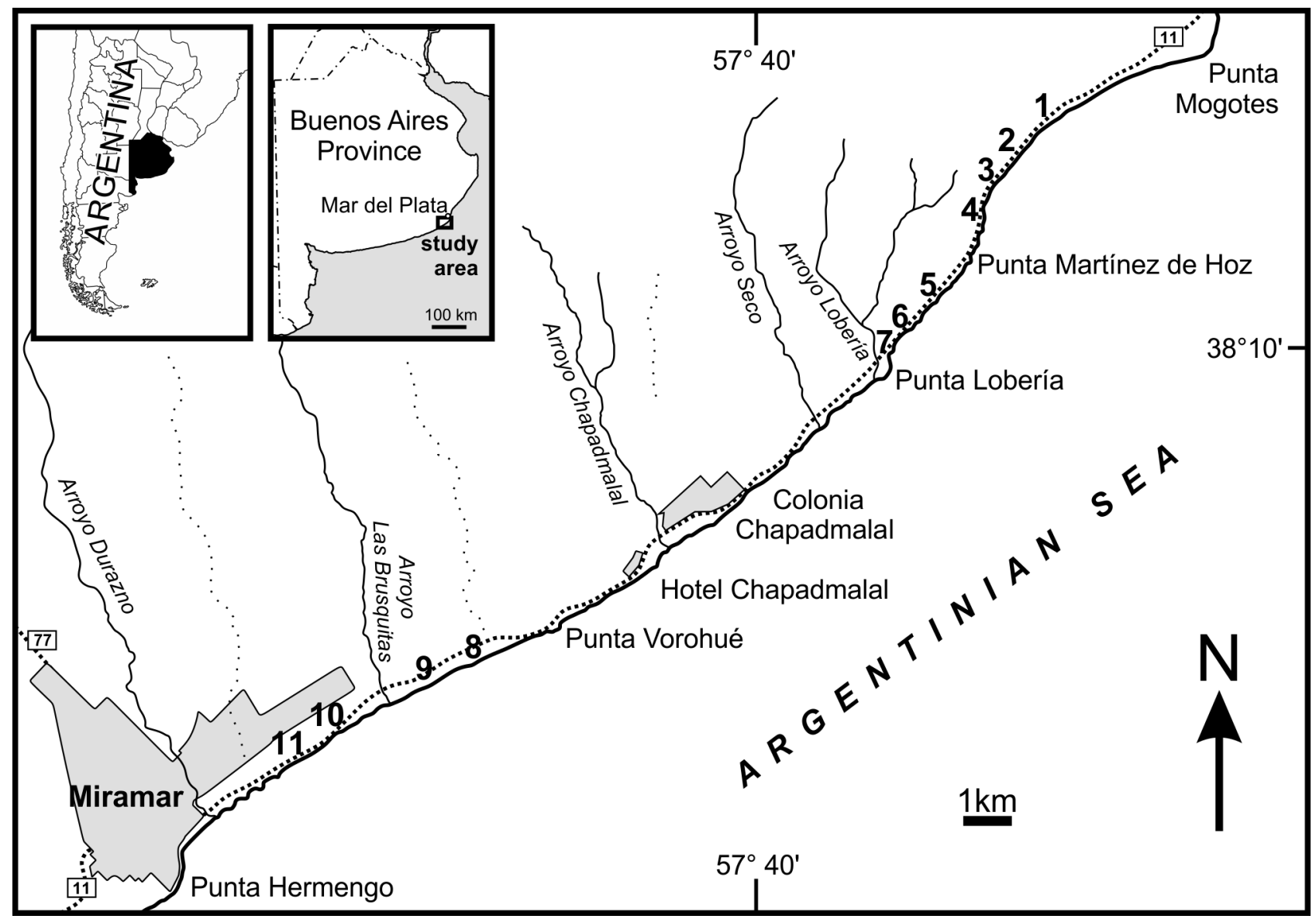

Figure 1. Map showing fossil localities in Buenos Aires Province, Argentina. 1, Las Vertientes; 2, Playa Serena; 3, Los Acantilados; 4, Barranca Los Lobos; 5, Las Palomas; 6, Playa de los Lobos; 7, La Estafeta; 8, Arroyo Seco; 9, San Eduardo; 10, Barranca Parodi; 11, Baliza Chica. 


\section{GEOLOGICAL AND STRATIGRAPHICAL CONTEXT}

Coastal cliffs between Mar del Plata and Miramar (Buenos Aires Province, Fig. 1) span an exposition of more than 30 kilometers of 12 to 25 meters of thickness. In this area, Ameghino (1908) defined an intermediate age, between the 'Hermosense' and the 'Ensenadense', for 'Piso Chapalmalense'. Later studies significantly modified the concept of 'Piso Chapalmalense' (e.g., Risso Dominguez, 1949a,b; Kraglievich, 1952, 1959a,b; see Taglioretti et al., 2014; Isla et al., 2015 for a comprehensive account of studies on this subject).

Eight litostratigraphic units are recognized along the cliffs: formations Chapadmalal, Barranca de los Lobos, Vorohué, San Andrés, Miramar, Arroyo Seco, Santa Isabel and Lobería (e.g., Kraglievich, 1952; Cione and Tonni, 1996, 2001).

The Chapadmalal Formation is the oldest unit cropping out in this area and it is composed of fine to very fine red limestones deposited in a subaerial environment. Kraglievich (1952) divided the Chapadmalal Formation in alternating levels (level I to level XV) of fine sandstones (uneven levels, 1-1.5 m thick) and very fine sandstones with a high proportion of limestones (even levels, 0.5-1.5 m thick). Zárate (1989) subdivided the Chapadmalal Formation into two alloformations and recognized seven paleosoils (P1 to P7). The Playa San Carlos Alloformation includes paleosoils P1 to P5 while the Playa Los Lobos Alloformation includes paleosoils P6 and P7 (Fig. 2).

The biostratigraphic basis of the Upper Chapadmalalan Stage/Age (late Pliocene) is the 'Paraglyptodon chapadmalensis zone' and it extends from the base of the Chapadmalal Formation (paleosoil P1) to paleosoil P5 (see Cione and Tonni, 1995a,b,c, 2001).

Datings of paleosoil P6 indicated an estimated age of 3.27 (£0.08) Ma (Schultz et al., 1998). Zárate (2005) estimated an age of 4.5 to $3.2 \mathrm{Ma}$ for the Chapadmalal Formation.

The material hereby studied was recovered from several levels of the Chapadmalal Formation (Fig. 2; see detailed stratigraphic provenance in Systematic Paleontology section).

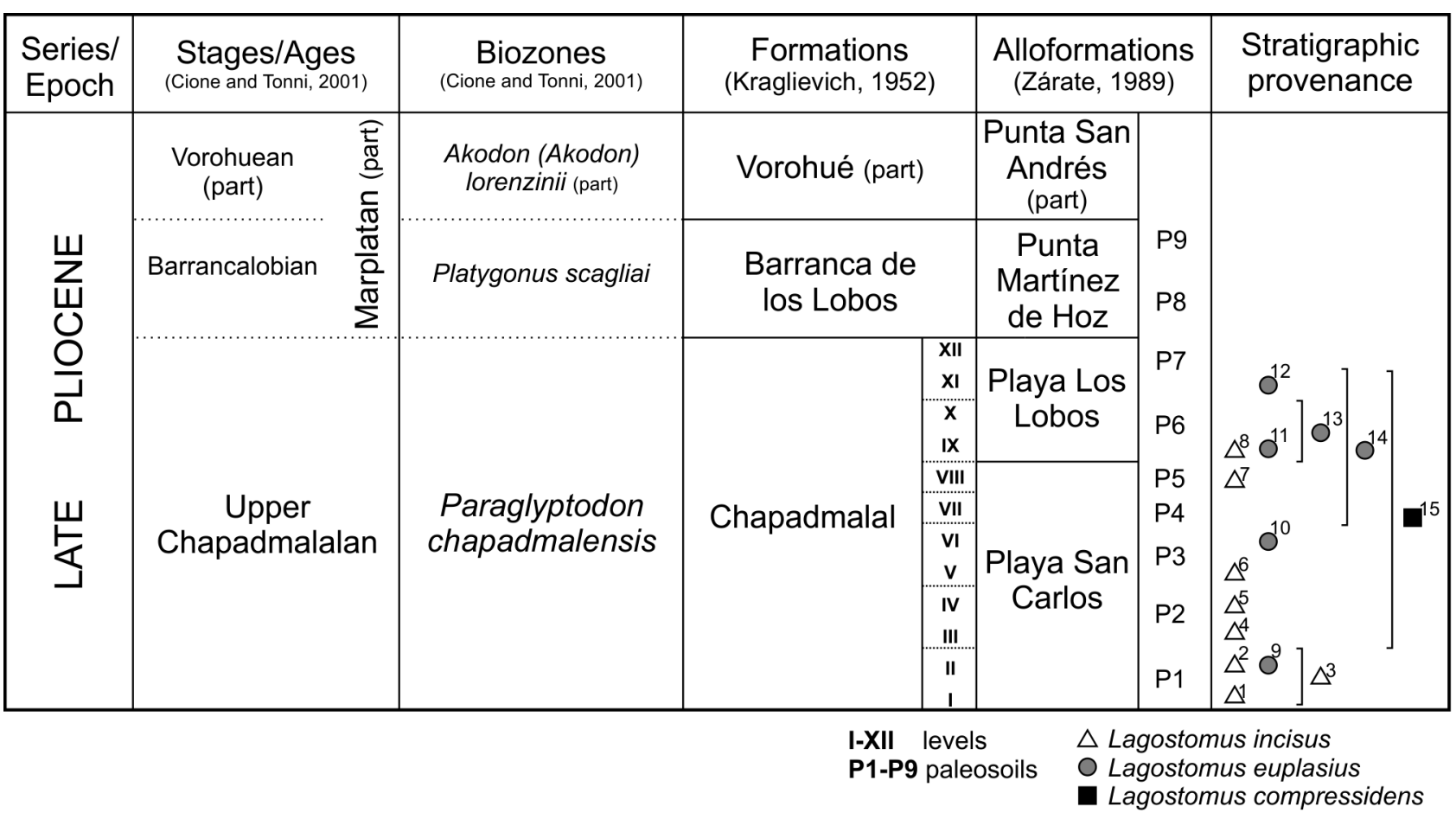

Figure 2. Chronostratigraphic scheme of the Chapadmalalan Stage/Age and precise stratigraphic provenance of studied specimens. 1, MLP-Pv 01-I-10-53; 2, MLP-Pv 01-I-10-38, 01-I-10-41, 01-I-10-54; 3, MLP-Pv 91-IV-5-214, 91-IV-5-258; 4, MLP-Pv 01-I-10-37, 01-I-10-52; 5, MLP-Pv 01-I-10-34, 01-I-10-47; 6, MLP-Pv 01-I-10-30, 01-I-10-31, 01-I-10-32, 01-I-10-33; 7, MLP-Pv 01-I-10-35; 8, MLP-Pv 01-I-10-44; 9, MLP-Pv 01-I-10-36, 01-I-10-49, 01-I-10-55; 10, MLP-Pv 01-I-10-56; 11, MLP-Pv 01-I-10-40, 01-I-10-50; 12, MLP-Pv 01-I-10-39; 13, MLP-Pv 91-IV-5-334, 91-IV-5-350, 52-IX-28-62, 52-X-4-21; 14, MLP-Pv 52-X-1-13, 52-IX-29-74, 52-XI-5-8; 15, MLP-Pv $90-V I-1-1$. 


\section{PREVIOUS STUDIES OF THE CHAPADMALALAN VIZCACHAS}

Ameghino (1908) described seven species from 'Piso Chapalmalense', included them in the genus 'Viscaccia' (see above) and mentioned that some undetermined specimens were very similar to 'Lagostomus spicatus' (Ameghino, 1908: 424), a junior synonym of Lagostomus incisus (see Rasia and Candela, 2013; see also Fig. 3).

Kraglievich (1926) studied specimens of lagostomines from the Chapadmalal Formation previously studied by Ameghino (1908) and created, based on cranial and postcranial characteristics, the subgenus Lagostomopsis. Within such subgenus, Kraglievich (1926) included all the Chapadmalalan species of Lagostomus and, in the same contribution, introduced the possibility of also including all preChapadmalalan species (i.e., those from the Monte Hermoso Formation and from 'Araucanense' and 'Mesopotamiense'; see Ameghino, 1883, 1886, 1888, 1891; Rovereto, 1914). In a later work, Kraglievich (1934) proposed Lagostomopsis as a separate genus. Nevertheless, Francis and Mones $(1965,1966,1968)$ considered that the differences between Lagostomus and Lagostomopsis were not sufficient to differentiate two genera and thus maintained Lagostomopsis as a subgenus of Lagostomus.

Recently, Rasia and Candela (2013) reported the presence of Lagostomus incisus, originally described for the Monte Hermoso Formation (Buenos Aires Province; Ameghino, 1888), in the Chapadmalal Formation.

Following the proposal of Francis and Mones (1965, 1966, 1968), all recognized Chapalmalalan species (see Figs. 3,4 and 5) are herein considered as belonging to the genus Lagostomus.

\section{SYSTEMATIC PALEONTOLOGY}

Order Rodentia Bowdich, 1821

Suborder HystricognathI Tullberg, 1899

Infraorder Caviomorpha Wood and Patterson

in Wood, 1955

Family CHINCHILLIDAE Bennett, 1833

Subfamily LAgostominAE (Wiegmann, 1835)

Genus Lagostomus Brookes, 1828
Type species. Lagostomus trichodactylus Brookes, 1828 (=Dipus maximus Desmarest, 1817).

\section{Lagostomus incisus Ameghino, 1888}

Figs. 3.1-8, 6.1-2

1888. Lagostomus incisus Ameghino, 1888: 9.

1889. Lagostomus angustidens Moreno, 1888; Ameghino 1889: 182. non Burmeister, 1866: 147.

1914. Viscaccia incisa (Ameghino); Rovereto, 1914: 137.

2013. Lagostomus spicatus Ameghino, 1888: 10; Rasia and Candela, 2013: 244.

2013. Lagostomus (Lagostomopsis) incisus (Ameghino, 1888). Rasia and Candela, 2013: 244.

2013. Lagostomus intermedius Moreno, 1888; Ameghino 1889: 184. Rasia and Candela, 2013: 244.

Holotype. MACN-A 1112, incomplete skull with complete dentition. Monte Hermoso Formation (early Pliocene). Recently, Rasia and Candela (2013), following Mones's (1986) statement ensuring the holotype was lost, designated MACN-A 1112 as the neotype of Lagostomus incisus. However, according to that expressed by Ameghino (1888, 1889; also Kramarz pers. comm.), the specimen MACN-A 1112 is the original holotype. Thus, it is hereafter pertinent to rectify the taxonomic assignation of MACN-A 1112 as the holotype of $L$. incisus instead of the neotype of this species (Rasia and Candela, 2013). Note that, in both cases, the material considered as type (herein) or neotype (previously) is the same specimen.

Referred material. MLP-Pv 88-VI-1-2*, skull fragment with right P4-M3 and left P4-M2, left mandible fragment with p4-m3, two isolated upper incisors, one caudal vertebra, right humerus, pelvis fragments and left femur; MLP-Pv 91-IV-5-223, right mandible; MLP-Pv 91-IV-5-214*, left mandible fragment with incisor and $\mathrm{p} 4-\mathrm{m} 2$ as well as left upper incisor; MLP-Pv 91-IV-5-258*, almost complete skull with right and left incisors and $\mathrm{P} 4-\mathrm{M} 3$, right radius, right ulna fragment, right femur, left femur fragment, left tibia, left calcaneus, right astragalus, right metatarsals II, III and IV, right proximal phalanxes II, III and IV; MLP-Pv 01-I-1030, left mandible with p4-m3; MLP-Pv 01-I-10-31, left mandible fragment with p4-m3; MLP-Pv 01-I-10-32, incomplete skull with right and left incisors and P4-M3; MLPPv 01-I-10-33, complete skull with right and left incisors as well as P4-M3 and right tibia; MLP-Pv 01-1-10-34, right maxillary fragment with M1-M2; MLP-Pv 01-I-10-35, right mandible with incisor and p4-m3, vertebra, scapula, pelvis 
fragment, humerus, tibia distal fragment, femur proximal fragment, metatarsal, three hindlimb phalanxes; MLP-Pv 01-I-10-37, anterior skull fragment with right and left upper incisors; MLP-Pv 01-I-10-38, left maxillary fragment with P4-M1; MLP-Pv 01-I-10-41, right mandible with incisor fragment and p4-m3; MLP-Pv 01-I-10-44, left mandible with incisor fragment and p4-m3; MLP-Pv 01-I10-47, skull fragment with right and left $\mathrm{P} 4-\mathrm{M} 3$ and right mandible with p4-m3; MLP-Pv 01-I-10-52, right mandible with incisor fragment, $\mathrm{m} 2$ and fragment of $\mathrm{m3}$; MLP-Pv 01-I-10-53, skull fragment; MLP-Pv 01-I-10-54, right mandible fragment with $\mathrm{p} 4-\mathrm{m} 3$, axis fragment, radius fragment and tibia fragment.

Specimens identified with an asterisk ( ${ }^{*}$ ) were already referred to Lagostomus incisus by Rasia and Candela (2013). Geographic occurrence. Coastal cliffs between Mar del Plata and Miramar, Buenos Aires Province (Fig. 1). MLP-Pv 88-VI1-2 and 01-I-10-52 from Las Vertientes; MLP-Pv 91-IV-5214, 91-IV-5-2 and 91-IV-5-258 from Fortin-88; MLP-Pv 01-I-10-30, 01-I-10-31, 01-I-10-37, 01-I-10-38, 01-I-1041, 01-I-10-47, 01-I-10-53 and 01-I-10-54 from Barranca de Los Lobos (formerly Bajada Martínez de Hoz); MLP-Pv 01-I-10-32, 01-I-10-34 and 01-I-10-35 from Las Palomas; MLP-Pv 01-I-10-33 from San Eduardo; and MLP-Pv 01-I10-44 from Estafeta.

Lagostomus incisus have also been recorded in Farola Monte Hermoso (see Ameghino, 1888; Rasia and Candela, 2013) and Cascada Grande (see Rasia and Candela, 2013) in Buenos Aires Province.

Stratigraphic occurrence. Chapadmalal Formation (Upper Chapadmalalan, late Pliocene; Fig. 2). MLP-Pv 91-IV-5-214 and 91-IV-5-258 from paleosoil P1; MLP-Pv 01-I-10-53 from level I; MLP-Pv 01-I-10-38, 01-I-10-41 and 01-I-1054 from level II; MLP-Pv 01-I-10-37 and 01-I-10-52 from level III; MLP-Pv 01-I-10-34 and 01-I-10-47 from level IV; MLP-Pv 01-I-10-30, 01-I-10-31, 01-I-10-32 and 01-I-1033 from level V; MLP-Pv 01-I-10-35 from level VIII; MLP-Pv 01-I-10-44 from level IX. MLP Pv 88-VI-1-2 from an undetermined level of the Chapadmalal Formation (see Comments below).

Lagostomus incisus have also been recorded in the Monte Hermoso Formation (early Pliocene; see Ameghino, 1888; Rasia and Candela, 2013) and in the Irene 'formation' (Pliocene?; see Rasia and Candela, 2013 but also Verzi and
Montalvo, 2008; Verzi et al., 2008; Prevosti and Pardiñas, 2009 for further discussion regarding the age of the Irene 'formation'), both in Buenos Aires Province.

Diagnosis. See Rasia and Candela (2013: 245) and Rasia (2016: 90-91). The diagnoses proposed by Rasia and Candela (2013) could be, after a complete revision of the species of Lagostomus is concluded, reassessed in further contributions.

\section{Description and comparisons}

Rasia and Candela (2013) recently presented an emended diagnosis and redescription of this species (see also Rasia, 2016). Therefore, herein, we comment only on some aspects of the anatomy which were not discussed in the abovementioned works.

Skull. In contrast with Lagostomus maximus or L. euplasius (Fig. 4.3), the ventral surface of the zygomatic arch is straight (Fig. 3.3).Yet, both present a ventral projection near the maxillo-jugal suture.

Postcranial skeleton. The calcaneus of Lagostomus incisus presents a secondary sustentacular facet akin to the one described by Candela and Picasso (2008) for the living chinchillids L. maximus and Chinchilla.

\section{Comments}

Several species have been synonymized with Lagostomus incisus (see Ameghino, 1889; Rasia and Candela, 2013). Ameghino (1889) stated that 'Lagostomus angustidens' (created by Moreno, 1888) was not only a synonym of $L$. incisus but also a name previously used by Burmeister (1866) and also considered 'Lagostomus intermedius', which was described by Moreno (1888), a synonym of 'L. spicatus'. Later, Rasia and Candela (2013) synonymized 'L. spicatus' with $L$. incises and thus ' $L$. intermedius' was then considered a synonym of $L$. incisus. The holotypes of ' $L$. angustidens' (Moreno, 1888) and 'L. intermedius' are at present lost.

Most of the specimens of Lagostomus incisus studied herein were recovered from the Playa San Carlos Alloformation (sensu Zárate, 1989) while MLP-Pv 01-I-10-44 was the only specimen recovered from lower levels of the Playa Los Lobos Alloformation (Fig. 2). The specimen MLP-Pv 88-VI-12 came from Las Vertientes, where levels III to XI crop out (see Kraglievich, 1952), and would therefore issue from either the Playa San Carlos or the Playa Los Lobos alloformations. 
Lagostomus euplasius (Ameghino, 1908)

Figs. 4.1-11, 6.3-4

1908. Viscacia (sic) euplasia Ameghino, 1908: 424-425.

1914. Viscaccia euplasia Ameghino. Rovereto, 1914:192, fig. 74.4, Lam. 26 fig. 5, 5 a.

1926. Lagostomus (Lagostomopsis) euplasius (Ameghino). Kraglievich, 1926: lam. 1, figs. 3, 4.

Viscacia (sic) loberiaense Ameghino, 1908: 425 new synonymy.

Viscaccia loberianese Ameghino. Rovereto, 1914: 193, fig. 74.3 new synonymy.

Viscacia (sic) definita Ameghino, 1908: 424 new synonymy.

Viscaccia definita Ameghino. Rovereto: 1914: 192 new synonymy. Viscacia (sic) chapalmalense Ameghino, 1908: 424 new synonymy. Viscaccia chapalmalense Ameghino. Rovereto, 1914: 192 new synonymy.
Emended diagnosis. Lagostomine of middle to small size; smaller than Lagostomus maximus, L. egenus, L. cavifrons, L. debilis, L. compressidens and L. incises; larger than L. Iaminosus; and similar in size to L. pretrichodactyla, L. antiquus, L. heterogenidens and L. minimus. Premaxillaries posteriorly longer than nasals. Palate formed by maxillaries and palatines in equal proportion. Incisors with yellowish enamel. Hipoflexa and hipoflexids with thicker cement than in L. antiquus, L. incisus, L. compressidens, L. debilis, L. heterogenidens, L. minimus, L. cavifrons and L. maximus. Upper cheek teeth more compressed anteroposteriorly than in Lagostomus pretrichodactyla, L. compressidens and L. maximus yet
(1)

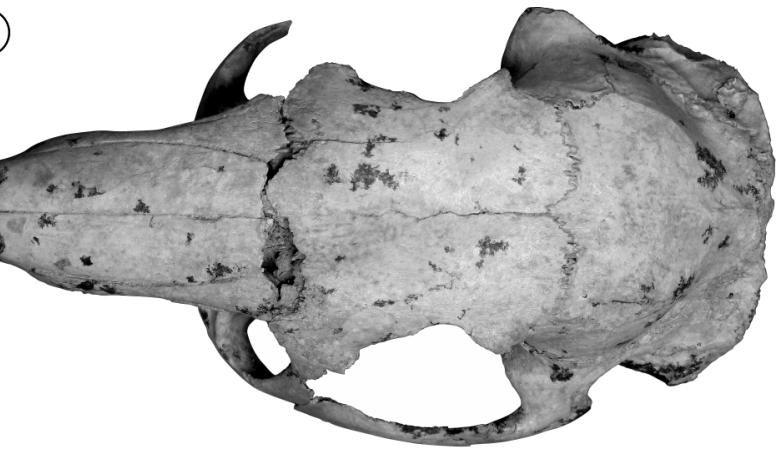

(3)

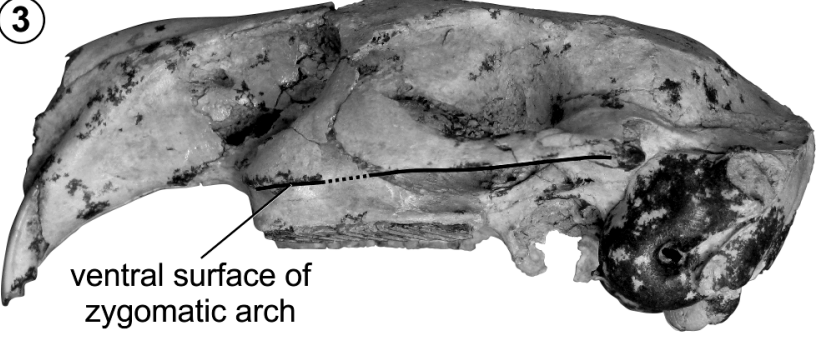

(2)

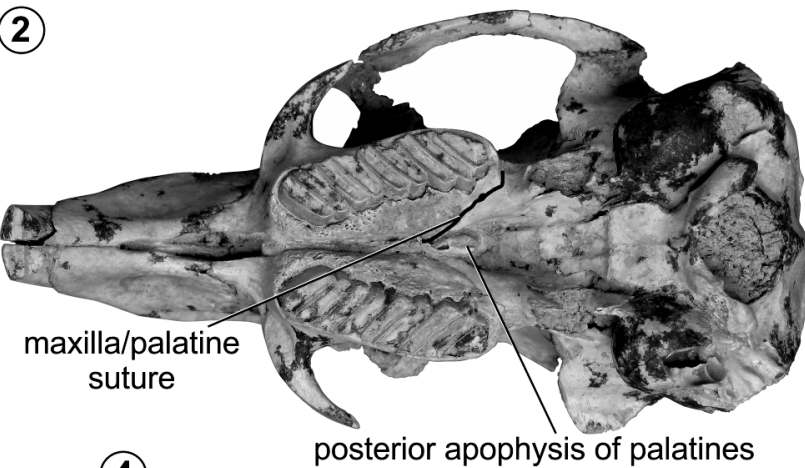

(4)
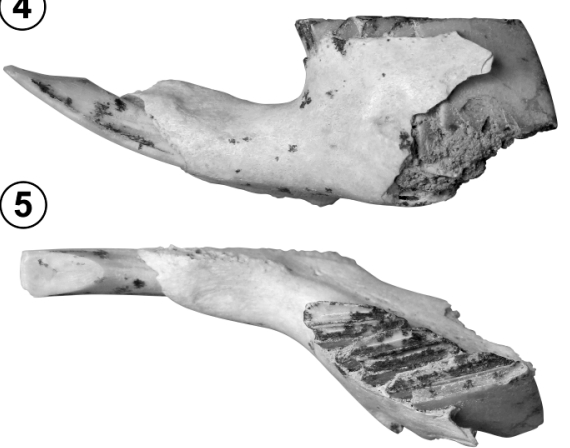

(6)

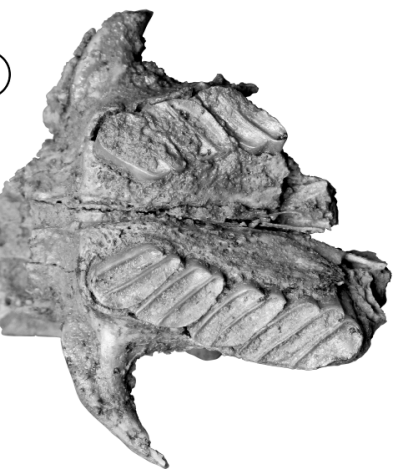

(7)

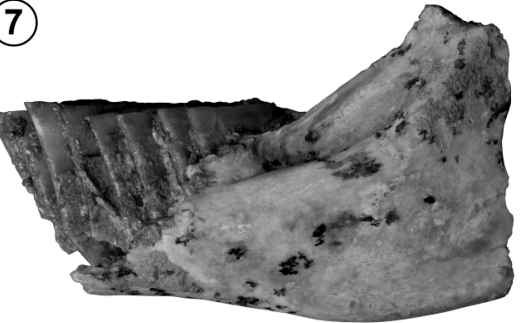

$(8)$

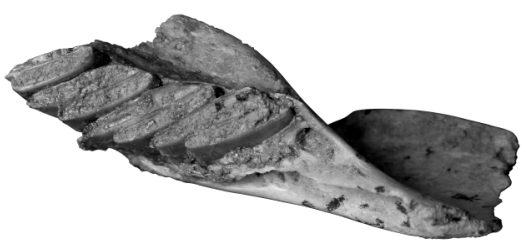

Figure 3. Lagostomus incisus from the Chapadmalal Formation. 1-3, MLP-Pv 91-IV-5-258; 1, skull in dorsal view; 2, skull in ventral view; 3, skull in lateral view; 4-5, MLP-Pv 91-IV-5-214; 4, left mandible in lateral view; 5, left mandible in dorsal view; 6-8, MLP-Pv 88-VI-1-2; 6, palate in ventral view; $\mathbf{7}$, left mandible in lateral view; 8 , left mandible in dorsal view. Scale bar $=1 \mathrm{~cm}$. 
less than in $L$. incisus and forming a more acute angle with the sagittal plane than in L. antiquus, L. pretrichodactyla, $L$. compressidens, L. cavifrons and L. maximus though less than in L. incisus. Lower cheek teeth are less compressed anteroposteriorly than in L. incisus and L. laminosus and more compressed than in L. pretrichodactyla, L. compressidens, $L$. cavifrons and L. maximus and thus similar to L. antiquus, $L$. debilis, L. heterogenidens and L. minimus. Lower cheek teeth laminae forming a more acute angle with the sagittal plane than in L. maximus, L. cavifrons, L. compressidens, L. pretrichodactyla, L. minimus, L. heterogenidens and L. debilis but less than in L. incises, thus being similar to L. antiquus. Humerus shows a fully formed supracondyloid canal.

Holotype. MACN-Pv 6163, complete skull with right and left incisors and P4-M3, mandibles with right and left incisors and p4-m3 (Figs. 4.1-4).

Referred material. MACN-Pv 5986 (holotype of 'Viscaccia definita'), right mandible fragment with incisor and $\mathrm{p} 4-\mathrm{m} 2$ (Figs. 4.6-7); MACN-Pv 5985 (holotype of ' $V$. chapalmalense'), left mandible with p4-m2, symphyseal portion of right mandible and two isolated lower incisors (Fig. 4.11); MLP-Pv 54-X-13-1 (holotype of ' V. loberiaense'), incomplete skull with left incisor, right and left P4-M3, atlas fragment, axis fragment, seven lumbar vertebrae, one sacral vertebra, six caudal vertebrae, left humerus, left metacarpal IV, pelvis, right and left femurs, right and left tibiae, right fibula fragment, right astragalus, right calcaneus, right navicular, right proximal phalanx of digit III, right upper incisor, P4 and M3 (Figs. 4.8-10); MLP-Pv 52-IX-28-62, maxillae with left P4$\mathrm{M} 3$ and right $\mathrm{P} 4-\mathrm{M} 2$ as well as left premaxillary fragment; MLP-Pv 52-IX-29-74, two right lower incisors, two right tympanic bullae, two lumbar vertebrae, right scapula fragment, left humerus, left humerus distal fragment, three incomplete right and left humerus, left tibia, right astragalus, right calcaneus, right tarsals II and III, left tarsal II; MLP-Pv 52-X-1-13, palate with left $\mathrm{P} 4-\mathrm{M} 3$ and right $\mathrm{P} 4-\mathrm{M} 1$ and $M 3$, right premaxilary fragment with incisor, fragments of posterior portion of the skull; MLP-Pv 52-X-4-21, anterior portion of the skull with right and left incisors, right P4-M3, left P4-M2, right mandible with incisor and p4-m3, sacral vertebrae, left tibia, left astragalus, left calcaneus, left tarsals II, III and IV, complete digit III of hindlimb; MLP-PV 52-XI-5-8, left mandible with incisor and p4-m3, right femur and right tibia from different individuals; MLP-Pv 91-
IV-5-334, anterior fragment of the skull with right and left incisors and P4-M3, atlas, axis and seven cervical vertebrae; MLP-Pv 01-I-10-36, anterior portion of the skull with right and left incisors, right P4-M1, left P4-M3, occipital portion of the skull and right tympanic bulla; MLP-Pv 01-I10-39, palate fragment with right and left P4-M2; MLP-Pv 01-I-10-40, fragment of right maxillary with P4-M1, fragment of right mandible with incisor and p4, fragment of left mandible with $\mathrm{p} 4-\mathrm{m3}$, acetabular portion of pelvis; MLP-Pv 01-I-10-49, skull roof fragment, left tibia fragment, right and left humerus, isolated teeth; MLP-Pv 01-I-10-50, anterior portion of the skull with right and left P4-M3; MLPPv 01-I-10-55, right mandible fragment with p4-m3, posterior skull portion, ulna, radius, left femur distal portion, left tibia, articulated left foot, isolated tarsal element; MLPPv 01-I-10-56, right mandible fragment with p4-m2.

Geographic occurrence. Coastal cliffs between Mar del Plata and Miramar, Buenos Aires Province, Argentina (Fig. 1).

Holotype of Lagostomus euplasius (MACN-Pv 6163), MACN-Pv 5986 (holotype of 'Viscaccia definita') and MACNPv 5985 (holotype of ' $V$. chapalmalense') were recovered from 'Chapalmalal'. MLP-Pv 54-X-13-1 (holotype of 'V. loberiaense') was recovered from an undetermined site on the Atlantic coast between Mar del Plata and Miramar. MLP-Pv 01-I-10-36 comes from Los Acantilados; MLP-Pv 01-I-1055, from Playa Serena; and MLP-Pv 01-I-10-39, 01-I-1049 and 01-I-10-56, from Barranca de los Lobos (formerly Bajada Martínez de Hoz). MLP-Pv 01-I-10-50 was recovered from Estafeta; MLP-Pv 01-I-10-40, from San Eduardo; and MLP-Pv 91-IV-5-334 and MLP-Pv 91-IV-5-350, from Las Brusquitas. MLP-Pv 52-IX-28-62 and MLP-Pv 52-X-421 were collected between Las Brusquitas and Vuelta Mala while MLP-Pv 52-IX-29-74 and MLP-Pv 52-X-1-13 were collected between Las Brusquitas and Punta Vorohué. MLPPv 52-XI-5-8 comes from Miramar.

Lagostomus euplasius have been also recorded in Farola Monte Hermoso (Mones, 1980; Rasia, 2016) and Cascada Grande (Frenguelli, 1928; Rasia, 2016), in Buenos Aires Province, Argentina, as well as in the Maldonado Department in Uruguay (Francis and Mones, 1966).

Stratigraphic occurrence. Chapadmalal Formation (Upper Chapadmalalan State/Age, late Pliocene; Fig. 2).

Holotype of Lagostomus euplasius (MACN-Pv 6163), MACN-Pv 5986 (holotype of 'Viscaccia definita), MACN-Pv 
5985 (holotype of 'V. chapalmalense) and MLP-Pv 54-X-13-

1 (holotype of 'V. loberiaense) come from 'Piso Chapalmalense'.

MLP-Pv 91-IV-5-334, MLP-Pv 91-IV-5-350, MLP-PV 52-IX-28-62 and MLP-Pv 52-X-4-21were recovered from levels IX to $X$ of the Chapadmalal Formation (see Fig. 2).

MLP-Pv 52-X-1-13, MLP-Pv 52-IX-29-74 and MLP-Pv 52-XI-5-8 were collected between levels VII and XI of the Chapadmalal Formation (see Fig. 2).

(1)

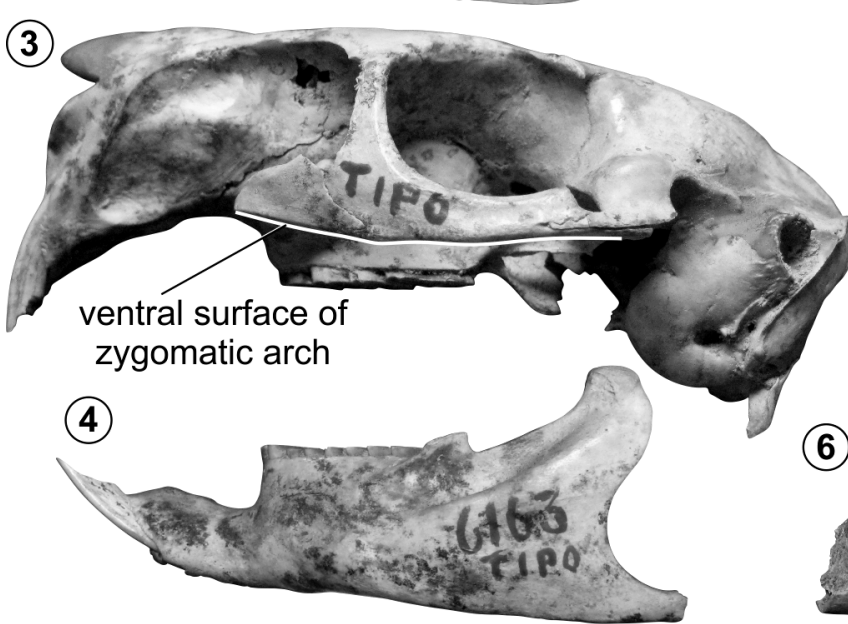

(8)

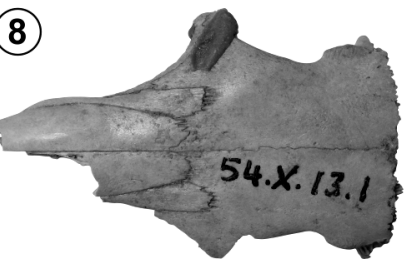

MLP-Pv 01-I-10-36, 01-I-10-49 and 01-I-10-55 come from level II; MLP-Pv 01-I-10-56, from level VI; MLP-Pv 01I-10-40 and 01-I-10-50, from level IX; and MLP-Pv 01-I10-39, from level XI.

Lagostomus euplasius have been also recorded in the Monte Hermoso Formation (early Pliocene; see Mones, 1980; Rasia, 2016), the Irene 'formation' (Pliocene?; see Rasia, 2016) and the Maldonado Formation (late Pliocene; Francis and Mones, 1966).
(5)

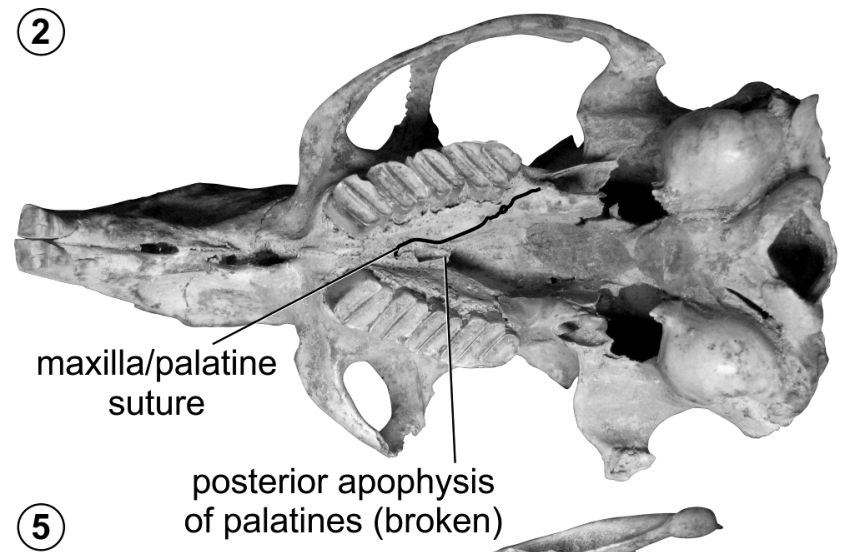

(6)

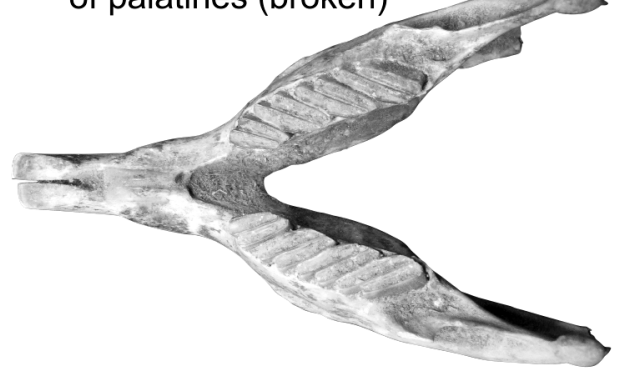

(7)

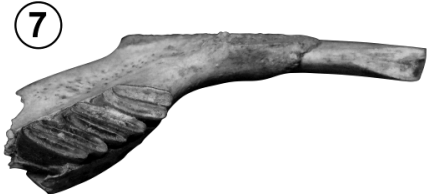

(10)

(11)

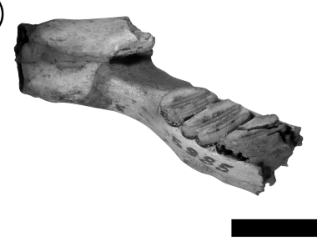

Figure 4. Lagostomus euplasius from the Chapadmalal Formation. 1-5, MACN-Pv 6163 (holotype); 1, skull in dorsal view; 2, skull in ventral view; 3, skull in lateral view; 4, mandibles in lateral view; 5, mandibles in dorsal view; 6-7, MACN-Pv 5986, holotype of 'Viscaccia definita'; 6, mandible in lateral view; 7, mandible in dorsal view; 8-10, MLP-Pv 54-X-13-1, holotype of 'Viscaccia loberiaense'; 8, skull fragment in dorsal view; 9, left palate portion in ventral view; 10, left humerus in posterior view; 11, MACN-Pv 5985, holotype of 'Viscaccia chapalmalense', left mandible and right mandibular fragment in dorsal view. Scale bar $=1 \mathrm{~cm}$. 


\section{Description and comparisons}

Skull. This is a small to medium sized lagostomine smaller than Lagostomus maximus, L. cavifrons, L. egenus, L. debilis, L. compressidens and L. incisus.

In comparison with the total length of the skull, the rostrum is short, thus resembling that of subadult individuals of Lagostomus maximus (Rasia, 2016). The nasals are wide and bulky in their anterior portion and become narrower from the middle point toward the posterior portion (Figs. 4.1, 4.8). Nasals are, as in Lagostomus pretrichodactyla and L. incises, equal in length or as much as $12.5 \%$ shorter than the frontals. In Lagostomus maximus, nasals are as long as the frontals in juvenile specimens but 50\% longer than the frontals in adult specimens. In L. compressidens and L. cavifrons, nasals are longer than the frontals. The premaxillaries extend beyond the posterior end of the nasals (Figs. 4.1, 4.8), as in Lagostomus pretrichodactyla and L. incisus. In $L$. compressidens, $L$. cavifrons and most of the specimens of $L$. maximus, premaxillaries and nasals reach the same level posteriorly.

Zygomatic arches are rather parallel to the sagittal plane, as in juvenile specimens of Lagostomus maximus. In adult specimens of the living species, the zygomatic arches are posteriorly divergent. As in Lagostomus maximus and differing from $L$. incisus (see above), the ventral surface of the zygomatic arch is slightly projected ventrally at the level of the maxillary-jugal suture (Fig. 4.3).

Temporal crests are long and well defined and the sagittal crest is short and well marked (Fig. 4.1). Both of the aforementioned features are common to subadult specimens and adult females of Lagostomus maximus.

The posterior palatine apophysis of the premaxillaries occur at the same dorso-ventral level than the diastema or slightly protrude ventrally, as in Lagostomus maximus, $L$. compressidens, L. pretrichodactyla, and L. cavifrons. In L. incisus, the premaxillary posterior palatine apohysis is situated dorsally with respect to the diastema (see Rasia and Candela, 2013). The interpremaxillar foramen is narrow but well developed. The incisive foramen is narrow and occupies less than half of the length of the diastema. Palatines reach anteriorly toward the posterior level of the P4, as in Lagostomus pretrichodactyla, L. compressidens, L. cavifrons and $L$. maximus, and present a posterior apophysis (Fig. 4.2). The palate is rather vaulted, with maxillaries and palatines forming a plane surface, as in Lagostomus pretrichodactyla. In L. maximus and L. compressidens, there is a shallow depression in the maxillary between the cheek teeth alveoli and the maxillary-palatine suture.

The tympanic bullae are rounded (Fig. 4.2), as in Lagostomus incisus and young specimens of L. maximus. In adult specimens of L. maximus, bullae are posterolateral-anteromedially elongated. The paraoccipital apohyses are strong and posteroventrally oriented (Fig. 4.3), as in Lagostomus maximus.

Mandibles. In comparison with the length of the lower cheek teeth series, the diastema is shorter than in Lagostomus incisus and L. compressidens. The masseteric crest is less developed than in L. maximus. The angular apophysis is slender. The coronoid apophysis is low in the mandible ramus and boasts a wide base, as in L. maximus. The postcondyloid apophysis is rounded and well developed, as in L. compressidens.

Upper teeth. The enamel of the upper incisors is yellowish. Although the color may be caused by diagenetic factors, it is noteworthy that the only specimens marked by yellowish enamel in the incisors are those which were assigned to Lagostomus euplasius (based on cheek teeth and skull characters). Such fact suggests that the color was original to such surface and is thus a diagnostic feature of this species.

The cheek teeth are more anteroposteriorly compressed than in Lagostomus pretrichodactyla, L. compressidens, L. cavifrons and $L$. maximus but less than in $L$. incisus (see Figs. 4.2 , 4.9, 6.3, 7). Cheek teeth laminae form a more acute angle with the sagittal plane than that which can be observed in Lagostomus maximus, L. cavifrons, L. compressidens, $L$. pretrichodactyla and $L$. antiquus though a less acute one than that of $L$. incisus.

The enamel band is thick but to a lesser extent than in Lagostomus pretrichodactyla. The cement of the hypoflexus is thicker than that of Lagostomus antiquus, L. incisus and L. compressidens. As in L. pretrichodactyla, hypoflexa are straight, with a short posterior curvature in the labial portion which is less marked than that of Lagostomus maximus. The anterior loph of the upper molars is more labially projected than the posterior loph, as in Lagostomus pretrichodactyla and L. maximus.

Lower teeth. As in the upper incisors, the enamel of the lower incisors is yellowish. 
The cheek teeth are less compressed anteroposteriorly than those of Lagostomus laminosus and L. incisus (see Figs. 4.5, 4.7, 4.11, 6.4, 7). Additionally, they are more compressed than in L. maximus, L. pretrichodactyla, L. compressidens and L. cavifrons, and similar to those of L. antiquus, $L$. heterogenidens, L. minimus and L. debilis.

Cheek teeth laminae form a more acute angle with the sagittal plane than that which is formed in Lagostomus maximus, L. pretrichodactyla, L. compressidens, L. heterogenidens, L. minimus and L. debilis. Yet, such angle is less acute than that of L. incisus, thus being similar to L. antiquus.

The cement layer of the hypoflexids is thicker than that of Lagostomus antiquus, L. incisus, L. compressidens, L. heterogenidens, $L$. minimus and $L$. debilis though similar to that of Lagostomus pretrichodactyla.

Postcranial skeleton. The humerus presents a fully formed supracondyloid canal above the medial epicondyle (Fig. 4.10). In Lagostomus incises, the supracondyloid canal is open or incomplete (see Rasia and Candela, 2013) and, in $L$. maximus, the canal is absent (see Kraglievich, 1926).

The calcaneus exhibits a secondary sustentacular facet distal to the sustentacular facet, as in the living chinchillids Lagostomus maximus and Chinchilla (see Candela and Picasso, 2008). Although this secondary facet is present in other fossil species of the genus, such as Lagostomus incisus (see above), it cannot be observed in other genera of Chinchillidae (i.e., Eoviscaccia, Prolagostomus and Pliolagostomus) because of the lack of preserved postcranial elements.

Other postcranial elements do not evidence significant differences with Lagostomus maximus or with other fossil species of the genus.

\section{Comments}

Most of the material of Lagostomus euplasius herein studied was recovered from the Playa San Carlos Alloformation and from basal levels of the Playa los Lobos Alloformation (Fig. 2). Only the specimens MACN-Pv 6163, MACN-Pv 5985, MACN-Pv 5986 and MLP-Pv 54-X-13-1 (holotypes of Lagostomus euplasius, 'Viscaccia chapalmalense', ' $\mathrm{V}$. definita' and ' $\mathrm{V}$. loberiaense') do not boast precise stratigraphic provenance within the Chapadmalal Formation.

The holotype of 'Viscaccia loberiaensis' (MLP-Pv 54-X13-1; Figs. 4.8-9) is indistinguishable from the holotype of
Lagostomus euplasius (MACN-Pv 6163; Figs. 4.1-3) with respect to skull morphology and cheek teeth characteristics. Probably being a juvenile specimen of these same species, their synonymy is therefore hereby proposed.

The holotypes of 'Viscaccia loberiaense', ' V. definita' (Figs. 4.6-7) and 'V. chapalmalense' (Fig. 4.11) share the presence of incisors with yellowish enamel and the lower cheek teeth features with the holotype of Lagostomus euplasius (Figs. 4.4-5). Therefore, their synonymy is hereby proposed.

Lagostomus euplasius was reported, based on different specimens (MLP-Pv 52-X-5-54 to 63), from the Monte Hermoso Formation by Mones (1980) and Rasia (2016).

Lagostomus compressidens (Ameghino, 1908) Figs. 5.1-5, 6.5-6

1908. Viscacia (sic) compressidens Ameghino, 1908: 424. 1914. Viscaccia compressidens Ameghino. Rovereto, 1914: 191, fig. 74.2 .

Viscacia (sic) indefinita Ameghino, 1908: 424 new synonymy. Viscaccia indefinita Ameghino. Rovereto, 1914: 192, fig. 74.1 new synonymy.

Emended diagnosis. Lagostomine smaller than Lagostomus maximus and $L$. cavifrons though approximately equal in size to $L$. incisus, L. debilis and L. egenus and larger than L. antiquus, L. Iaminosus, L. pretrichodactyla, L. euplasius, L. heterogenidens and $L$. minimus. Nasals extend posteriorly to the same level than the premaxilaries, thus differing from those of L. pretrichodactyla, L. incisus and L. euplasius. Maxillaries with a depression between cheek teeth alveoli and the palatines. Palatines more developed than maxillaries in palatal view. Palate less vaulted than in Lagostomus maximus and L. cavifrons. The root of the lower incisor reaches the posterior level of m2. Upper cheek teeth less compressed anteroposteriorly than in L. euplasius and L. incisus. Upper cheek teeth more perpendicular to the sagittal plane than in L. euplasius and L. incisus. Lower cheek teeth less compressed anteroposteriorly than in L. antiquus, L. laminosus, L. incisus and $L$. euplasius. Lower cheek teeth more perpendicular to the sagittal plane than in L. incisus, L. euplasius and L. antiquus. Cement present in the hypoflexus and hypoflexid, thinner than in L. pretrichodactyla.

Holotype. MLP-Pv 54-X-13-2, incomplete skull with right incisor and both complete cheek teeth series, left mandible with incisor and complete p4-m3 series (Figs. 5.1-4).

Referred material. MLP-Pv 54-X-13-4 (holotype of 'Vis- 
caccia indefinita'), palate with both cheek teeth series (Fig. 5.5); MLP-Pv 90-VI-1-1, right mandible with incisor and p4-m3.

Geographic provenance. The holotype and MLP-Pv 54-X-134 were recovered from an indetermined site between Mar del Plata and Miramar. MLP-Pv 90-VI-1-1 came from Las Vertientes (Fig. 1).

Stratigraphic provenance. Chapadmalal Formation (Upper Chapadmalalan, Iate Pliocene; Fig. 2). Both the holotype and MLP-Pv 54-X-13-4 were recovered from 'Piso Chapalmalense' sensu Ameghino (1908). MLP-Pv 90-VI-1-1 was collected from undetermined levels of the Chapadmalal Formation (see Comments below).

\section{Description and comparisons}

Skull. The description is mostly based on the holotype (MLPPv 54-X-13-2), which is the most complete specimen.

Lagostomus compressidens is a medium sized lagostomine approximately equal to adult females or subadult males of the living $L$. maximus and to adult individuals of $L$. incisus.

Nasals are broken in their anterior portion but the length of the preserved part is longer than that of the frontals, as in L. cavifrons and L. maximus. The nasals are approximately of equal width in all their length, as in L. incisus and L. maximus. Premaxillaries do not extend posteriorly beyond the nasals as occurs in Lagostomus pretrichodactyla, L. euplasius and $L$. incises. Instead, the premaxillaries extend posteriorly to the same level than the nasals (Fig. 5.1), as in L. maximus and L. cavifrons. Lacrimals are elongated as in Lagostomus maximus.

While temporal crests are long and well developed, the sagittal crest is, as observed in subadult males and adult females of Lagostomus maximus (see Rasia et al., 2011), short and well marked (Fig. 5.1). The skull roof is rather vaulted in lateral view, as in adult females and subadult males of L. maximus.

Posterior palatine apophysis of the premaxillary occurs at the same dorsoventral level than the diastema, as in Lagostomus maximus, L. cavifrons, L. euplasius and L. pretrichodactyla. The interpremaxillar foramen is narrow but well developed. The incisive foramen is wide and short.

The palatines extend anteriorly, reaching the level of the posterior margin of the $\mathrm{P} 4$ and forming an important por-
(1)

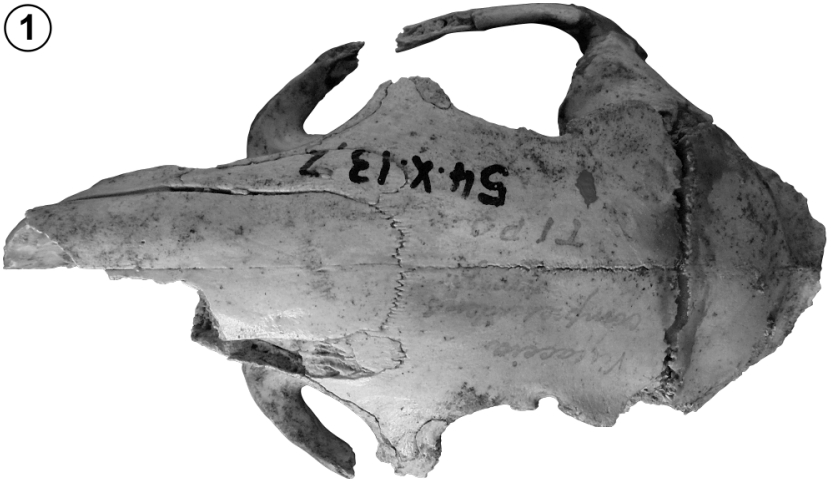

(3)

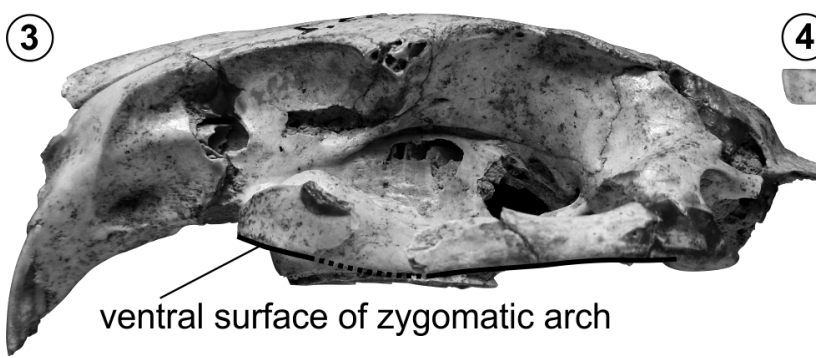

(2)

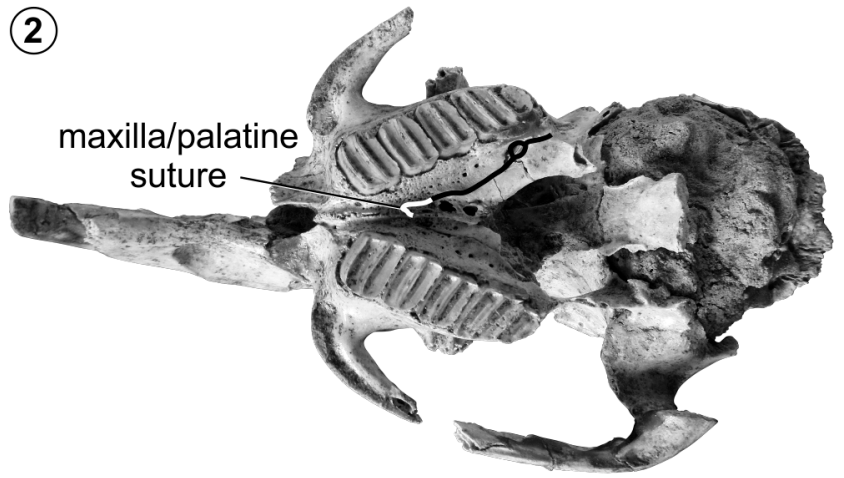

(4) (5)

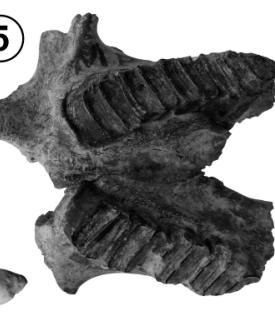

Figure 5. Lagostomus compressidens. 1-4, MLP-Pv 54-X-13-2 (holotype); 1, skull in dorsal view; 2, skull in ventral view; 3, skull in right lateral view (shown as left); 4, left mandible in dorsal view; 5, MLP-Pv 54-X-13-4, holotype of ' Viscaccia indefinita', palate in ventral view. Scale bar= $1 \mathrm{~cm}$. 
tion of the palate. In palatal view, the maxillary present a shallow depression between the cheek teeth alveoli and the maxillary-palatine suture. Such depression is also observed in Lagostomus maximus and L. cavifrons. Maxillae and palatines form a rather horizontal structure and the palate is not vaulted.

Mandibles. In comparison with the total length of the cheek teeth series, the diastema is shorter than that of Lagostomus maximus but longer than that of $L$. incisus and L. euplasius. Compared with L. maximus, the mandibular condyle is higher than the cheek teeth series. The postcondyloid process is more developed than in L. maximus.

Upper teeth. In comparison with specimens of Lagostomus maximus of similar size, the upper incisors present a greater transverse diameter and are shorter (less projected from the alveolar sheet).

The upper cheek teeth series is longer than in Lagostomus maximus, compared to the total length of the skull, and approximately equal to that of $L$. incisus.

Cheek teeth, sub-quadrangular and with straight margins, are similar to those of Lagostomus maximus and $L$. cavifrons. Cheek teeth are also less compressed anteroposteriorly than in Lagostomus euplasius and L. incisus, thus being approximately equal to those of $L$. pretrichodactyla, $L$. cavifrons and L. maximus (see Figs. 5.2, 5.5, 6.5, 7). Upper cheek teeth laminae are more perpendicular with respect to the sagittal plane than in Lagostomus incisus and L. euplasius, hence being approximately equal to those of $L$. antiquus, $L$. pretrichodactyla, L. cavifrons and L. maximus.

The third lobe of the M3 is well developed and marked by a larger anteroposterior diameter than that of the first two lobes.

There is cement in the hipoflexus of all cheek teeth and it is thinner than that of Lagostomus pretrichodactyla and $L$. euplasius, thus being similar to that of $L$. incisus.

Lower teeth. In parallel to what occurs with the upper incisors, the lower incisors are wider and shorter (less projected from the alveolar sheet) than in a specimen of Lagostomus maximus of equal size. A difference with respect to the other species of Lagostomus is given by the fact that the root of the lower incisor does not extend beyond the $\mathrm{m} 2$.

With respect to the total length of the mandible, the cheek teeth series is longer than that of Lagostomus maximus yet shorter than that of $L$. euplasius and $L$. incisus.
Cheek teeth are less compressed anteroposterioly than in Lagostomus antiquus, L. laminosus, L. incisus, L. euplasius, L. debilis, L. heterogenidens and L. minimus, thus being similar to those of L. pretrichodactyla, L. cavifrons, L. egenus and $L$. maximus (see Figs. 5.4, 6.6, 7).

Cheek teeth laminae form a less acute angle with respect to the sagittal plane than that of Lagostomus antiquus, L. incisus and $L$. euplasius. The nature of such angle is hence rather similar to that of $L$. pretrichodactyla, L. cavifrons and $L$. maximus.

There is cement in the hypoflexid of all cheek teeth and it is thinner than in Lagostomus pretrichodactyla and L. euplasius.

\section{Comments}

The holotype of 'Viscaccia indefinita' (MLP-Pv 54-X-134; Fig. 5.5) exhibits proportions, anatomic features of the upper cheek teeth and palatal morphology identical to those that characterize the holotype of Lagostomus compressidens (Fig. 5.2). Therefore, the synonymy of both species is hereby proposed.

The specimen MLP-Pv 90-VI-1-1, referred to as Lagostomus compressidens herein, is identical in size and in the morphology of lower cheek teeth and proportions of the
(1)

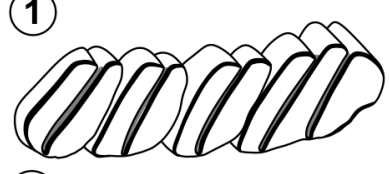

(3)

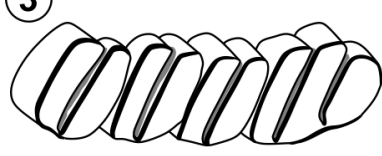

(5)

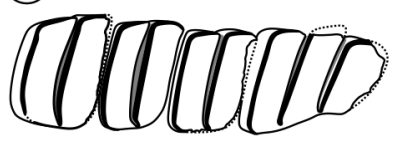

(2)

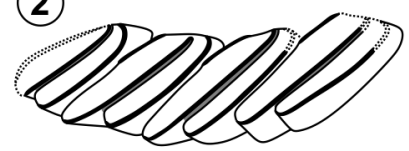

(4)

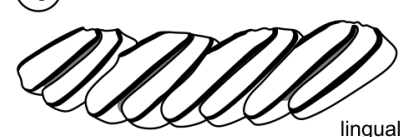

(6)

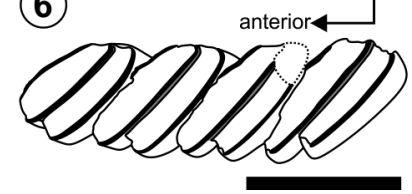

Figure 6. Compared schematic occlusal views of Lagostomus species from the Chapadmalal Formation. 1-2, Lagostomus incisus, MLP-Pv 88-VI-1-2; 1, scheme of right upper cheek teeth; 2 , scheme of left lower cheek teeth; 3-4, Lagostomus euplasius, MACN-Pv 6163; 3, scheme of right upper cheek teeth; 4, scheme of left lower cheek teeth; 5-6, Lagostomus compressidens, MLP-Pv 54-X-13-2; 5, scheme of right upper cheek teeth; 6 , scheme of left lower cheek teeth. Scale bar $=1 \mathrm{~cm}$. 
lower incisor and mandible to the holotype of this species.

The holotype of Lagostomus compressidens (MLP-Pv 54$X-13-2)$ and the holotype of 'Viscaccia indefinita' (MLP-PV 54-X-13-4) were recovered from 'Piso Chapalmalense' sensu Ameghino (1908). The specimen MLP-Pv 90-VI-1-1 was collected from Las Vertientes (see Fig. 1), where levels III to XI of the Chapadmalal Formation (sensu Kraglievich, 1952) crop out (see Fig. 2).

Lagostomus compressidens was recorded exclusively from the Chapadmalal Formation (late Pliocene).

\section{'Viscaccia arcuata' Ameghino, 1908 nomen dubium}

1908. Viscacia (sic) arcuata Ameghino, 1908: 425.

1914. Viscaccia arcuata Ameghino. Rovereto, 1914: 193.

Holotype. Currently lost.

\section{Comments}

Ameghino (1908) originally described this species based on skull remains and stated that it is small sized and presents a short, wide and vaulted skull. However, these features are also present in juvenile specimens of the living Lagostomus maximus and of fossil species such as $L$. incisus and $L$. euplasius. Therefore, 'Viscaccia arcuata' cannot be differentiated from other species based on such description and, given that the holotype has not been found at the MACN collection, is thus herein considered nomen dubium.

According to Mones (1986), the specimen MACN-PV 5983 is the holotype of this species. Nevertheless, this catalogue number corresponds to a right mandible and does not match the description of Ameghino (1908) based on skull remains.

\section{QUANTITATIVE ANALYSIS}

Upper cheek teeth. For the analysis based upon upper cheek teeth and given that all variables yield high positive loads (see Table 1), the first principal component (PC1) represents essentially size. The smaller specimens present lower values of PC1 while the larger ones present higher scores. The largest species with known upper cheek teeth are Lagostomus maximus, L. cavifrons, L. compressidens and L. incisus (see Fig. 8).

The second principal component (PC2) represents variations in the APD of P4-M2 and in the TD of M2-M3 (see Table 1). The species with more anteroposteriorly compressed upper cheek teeth is Lagostomus incisus, with negative scores. Lagostomus euplasius and L. cavifrons exhibit a
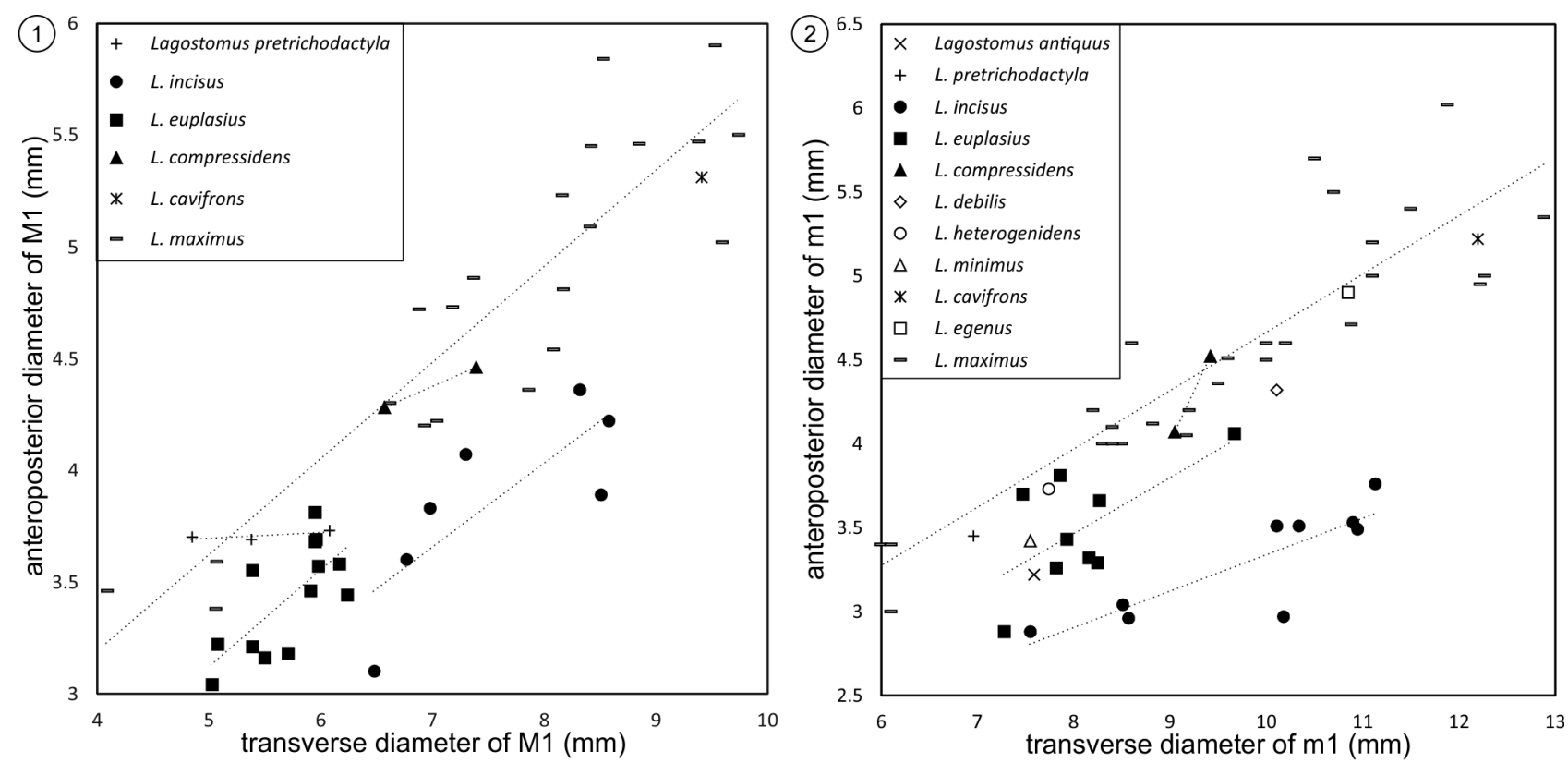

Figure 7. Bivariate graphic of dental measurements (in $\mathrm{mm}$ ) for species of Lagostomus. 1, first upper molar (M1) and 2, first lower molar (m1). Dotted lines indicate linear regression trend line for each species using least squares. 
TABLE 1 - Factor loadings of PC1 and PC2.

\begin{tabular}{|c|c|c|c|c|c|}
\hline \multicolumn{3}{|c|}{ PCA of upper cheek teeth } & \multicolumn{3}{|c|}{ PCA of lower cheek teeth } \\
\hline & $P C 1$ & $P C 2$ & & $P C 1$ & $P C 2$ \\
\hline$P 4 A P D$ & 0.296 & 0.399 & $p 4 A P D$ & 0.387 & 0.298 \\
\hline$P 4 T D$ & 0.360 & -0.111 & $p 4 T D$ & 0.383 & -0.144 \\
\hline$M 1 A P D$ & 0.319 & 0.383 & $m 1 A P D$ & 0.326 & 0.380 \\
\hline M1 TD & 0.382 & -0.255 & $m 1 T D$ & 0.335 & -0.225 \\
\hline$M 2 A P D$ & 0.338 & 0.403 & $m 2 A P D$ & 0.318 & 0.390 \\
\hline$M 2 T D$ & 0.376 & -0.336 & $m 2 T D$ & 0.333 & -0.396 \\
\hline M3 APD & 0.365 & 0.245 & $m 3 A P D$ & 0.324 & 0.344 \\
\hline M3 TD & 0.382 & -0.530 & $m 3 T D$ & 0.409 & -0.518 \\
\hline Eigenvalue & 0.303 & 0.024 & Eigenvalue & 0.270 & 0.050 \\
\hline Variance & $90 \%$ & $7 \%$ & Variance & $81 \%$ & $15 \%$ \\
\hline
\end{tabular}

moderate anteroposterior compression of upper cheek teeth. The rest of the species (L. pretrichodactyla, L. compressidens and L. maximus) present less compressed cheek teeth and yield positive scores (see Fig. 8).

Lower cheek teeth. In the analysis of the lower cheek teeth and given that all variables yield high positive loads (see Table 1), PC1 represents size. The smaller specimens present lower values while the larger ones yield higher ones (see Fig. 8). The species of larger size with known lower cheek teeth are Lagostomus maximus, L. cavifrons, L. egenus, L. debilis, L. compressidens and L. incisus.

PC2 represents variations in the APD of the $m 1-m 3$ and in the TD of the m2-m3 (see Table 1). Lagostomus incisus is the species with more compressed lower cheek teeth, with the lowest values. The species in which a moderate compression of the lower cheek teeth is observed are L. antiquus, L. euplasius and L. egenus. The species with less compressed lower cheek teeth are L. pretrichodactyla, L. debilis, L. heterogenidens, L. minimus, L. cavifrons and L. maximus (see Fig.8).

The Kruskal-Wallis test for the PC1 and PC2 of the PCA of the upper and lower cheek teeth indicates that the medians of the three species from the Chapadmalal Forma- tion are significantly different, except for the PC1 of lower cheek teeth (see Table 2) which represents essentially size.

According to these results, the three species recorded from the Chapadmalal Formation can be distinguished in terms of general size and anteroposterior compression of the cheek teeth. This thus supports the diagnostic value of the aforementioned characteristics (see Systematic Paleontology section).

\section{DISCUSSION AND CONCLUSIONS}

The comparative study of unpublished material with precise stratigraphic control from the Chapadmalal Formation allowed the identification of at least three of the seven species which were originally described by Ameghino (1908) for 'Piso Chapalmalense': Lagostomus incisus, L. euplasius and L. compressidens. The first one was originally described for the Monte Hermoso Formation (Ameghino, 1888) and later reported from the Irene 'formation' and the Chapadmalal Formation (Rasia and Candela, 2013). The second species was originally described for 'Piso chapalmalense' (sensu Ameghino, 1908) and later recorded in the Monte Hermoso Formation (Mones, 1980; Rasia, 2016), the Irene 'formation' 
(Frenguelli, 1928; Rasia, 2016) and the Maldonado Formation (Uruguay; Francis and Mones, 1966). The third species
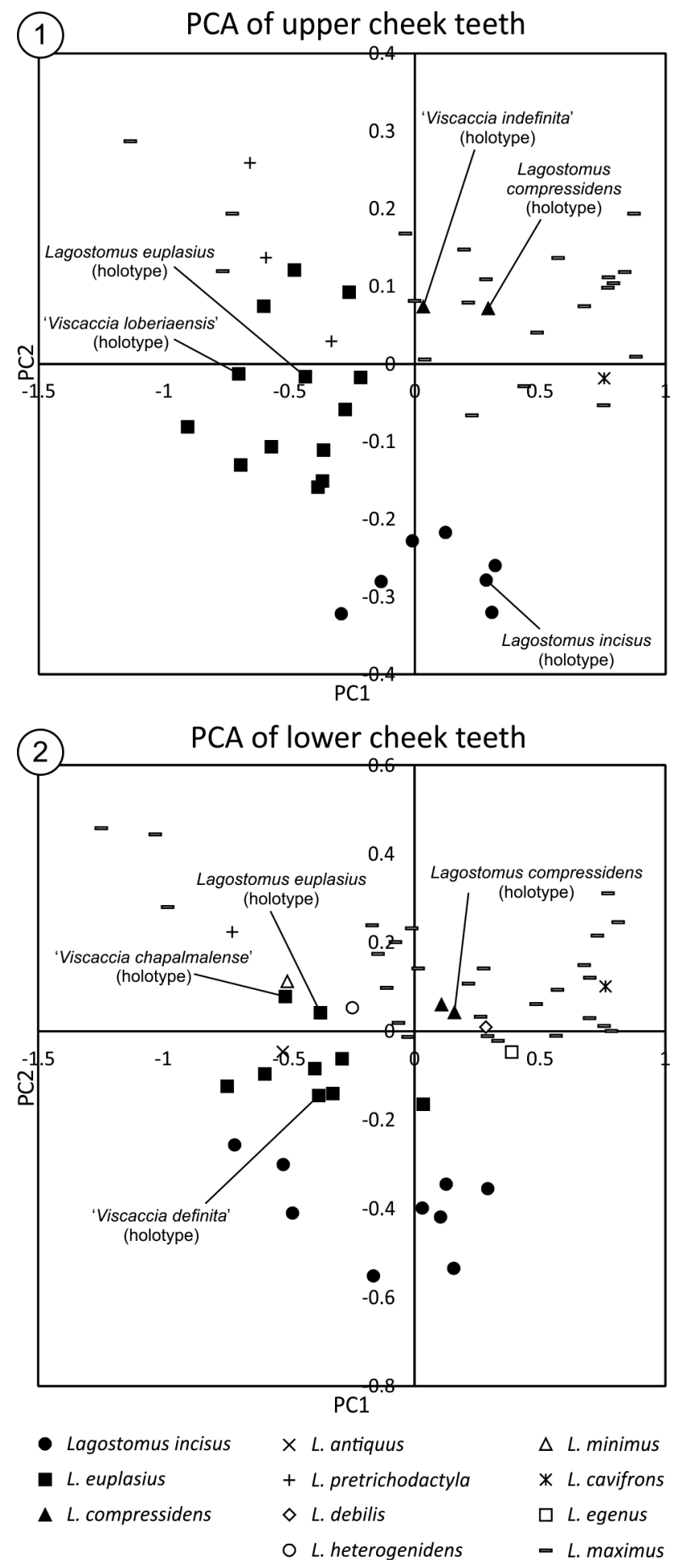

Figure 8. Plot of scores of PC1 and PC2 for dental measurements of species of Lagostomus. 1, upper cheek teeth; 2, lower cheek teeth. was described for 'Piso Chapalmalense' (sensu Ameghino, 1908) and is the only species recorded exclusively in the Chapadmalal Formation.

Ameghino (1908) diagnosed Lagostomus euplasius as being of very small size and presenting a deep palate and premaxillae extending posteriorly (on dorsal view); 'Viscaccia definita' was diagnosed as being marked by very striated lower incisors with a concave anterior surface; 'V. chapalmalense', by its small size, deep palate and M3 with the three lobes in the same plane; and ' $V$. loberiaense', by its very small size, long skull and yellowish enamel of the incisors. These four species share some of the abovementioned features, at least in the ones enough complete to be comparable. Therefore, the holotypes of 'Viscaccia loberiaense' (MLP-Pv 54-X-13-1), ' V. definita' (MACN-Pv 5986) and ' $V$. chapalmalense' (MACN-Pv 5985) are herein referred to Lagostomus euplasius.

Lagostomus compressidens was originally diagnosed (Ameghino, 1908) in terms of presenting compressed molars and a wide, shallow and flat palate. 'Viscaccia indefinita' was described as being similar to L. compressidens though smaller and with a deeper palate. Such differences are herein interpreted to be related to intraspecific variation and the holotype of 'Viscaccia indefinita' (MLP-Pv 54-X13-4) is, in this study, referred to Lagostomus compressidens.

The nominal species 'Viscaccia arcuata' was described for 'Piso Chapalmalense' (Ameghino, 1908) but the fact that the holotype of this species is currently lost and the original description (very small size and a short, wide and vaulted skull) does not admit its differentiation from other species derives in its labeling as a nomen dubium. The presence of this species in the Chapadmalal Formation is not confirmed and has yet to be re-evaluated.

The presence of Lagostomus incisus and L. euplasius in the Monte Hermoso and Chapadmalal formations (see Ameghino, 1888, 1908, Mones, 1980; Rasia, 2016; Rasia and Candela, 2013) indicates a Montehermosan-Chapadmalalan stratigraphic range for these two species. Additionally, the presence of $L$. incisus and $L$. euplasius in the Irene 'formation' (see Frenguelli, 1928; Rasia, 2016; Rasia and Candela, 2013) suggests a Montehermosan-Chapadmalalan age for, at least, part of this unit. Lagostomus incisus and $L$. euplasius represent the only species recorded during the whole Montehermosan-Chapadmalalan interval and 
TABLE 2 - Kruskal-Wallis test for PCA of species from Chapadmalal Formation.

\begin{tabular}{|c|c|c|c|c|c|}
\hline & $H-H c$ & $p$ & L. inc vs L. eup & L. inc vs L. com & L. eup vs L. com \\
\hline$P C 1$ - uct $P C A$ & 13.78 & 0.001019 & 0.0008741 & 0.8836 & 0.03375 \\
\hline$P C 2$ - uct $P C A$ & 14.37 & 0.0007594 & 0.0003626 & 0.05704 & 0.2696 \\
\hline$P C 1$ - Ict PCA & 5.525 & 0.06312 & 0.1333 & 0.2888 & 0.04513 \\
\hline$P C 2$ - Ict $P C A$ & 15 & 0.0005535 & 0.0004123 & 0.04513 & 0.1255 \\
\hline
\end{tabular}

Boldface indicates values higher than critical value. $a=0.05$; degrees of liberty= 2; critical value=5.991. Abbreviations: H, chi2; Hc, tie corrected; L. eup, Lagostomus euplasius; L. com, Lagostomus compressidens; L. inc, Lagostomus incisus; Ict, lower cheek teeth; uct, upper cheek teeth.

constitute the typical chinchillids during this lapse in central Argentina.

The specific diversity of the Montehermosan-Chapadmalalan lagostomines (with two species in the Montehermosan and at least three in the Chapadmalalan) is less significant than what was previously proposed; that is, with two species originally described for the Montehermosan (Ameghino, 1888) and seven, for the Chapadmalalan (Ameghino, 1908). Nonetheless, such numbers are still higher than those referred to the diversity observed in recent times, with only one species (e.g., Weir, 1974; Jackson et al., 1996).

The study of fossil Lagostominae could provide useful biostratigraphic information for the Pampean area given the great abundance of this group of rodents in late Cenozoic continental associations for which a more precise stratigraphic provenance is now known.

\section{AKNOWLEDGMENTS}

We want to thank M. Reguero (MLP), D. Flores (MACN), A. Kramarz (MACN), I. Olivares (MLP), and D. Verzi (MLP) for allowing us to study material under their care. We specially thank M. de los Reyes (MLP) for facilitating our access to the studied material which had been donated to the MLP by Silvio José Lorenzini. We thank S. Gouiric-Cavalli for her critical reading of an early version of the manuscript. Also, we would like to thank the editor, A. Kramarz, and the reviewers, M. Arnal and D. Croft, for their valuable suggestions which greatly improved the final version of the manuscript.

\section{REFERENCES}

Ameghino, F. 1883. Sobre una nueva colección de mamíferos fósiles recogidos por el Profesor Scalabrini en las barrancas del Paraná. Boletín de la Academia Nacional de Ciencias de Córdoba 5: 112-113.
Ameghino, F. 1886. Contribución al conocimiento de los mamíferos fósiles de los terrenos terciarios antiguos de Paraná. Boletín de la Academia Nacional de Ciencias de Córdoba 9: 5-228.

Ameghino, F. 1887. Enumeración sistemática de las especies de mamíferos fósiles coleccionados por Carlos Ameghino en los terrenos eocenos de Patagonia austral y depositados en el Museo de La Plata. Boletín del Museo de La Plata 1: 1-26.

Ameghino, F. 1888. Lista de las especies de mamíferos fósiles del Mioceno superior de Monte Hermoso, hasta ahora conocidas. Editorial Coni, Buenos Aires, $21 \mathrm{p}$.

Ameghino, F. 1889. Contribución al conocimiento de los mamíferos fósiles de la República Argentina. Actas de la Academia Nacional de Ciencias de Córdoba 6: 1-1027.

Ameghino, F. 1891. Mamíferos y aves fósiles argentinos. Especies nuevas, adiciones y correcciones. Revista Argentina de Historia Natural 1: 240-259.

Ameghino, F. 1908. Las Formaciones sedimentarias de la región litoral de Mar del Plata y Chapadmalal. Anales del Museo Nacional de Buenos Aires 10: 342-428.

Bertrand, O.C., Flynn, J.J., Croft, D.A., and Wyss, A.R. 2012. Two new taxa (Caviomorpha, Rodentia) from the Early Oligocene Tinguiririca Fauna (Chile). American Museum Novitates 3750: 1-36.

Bennett, E.T. 1833. Remarks on the family Chinchillidae and on a new genus referible (sic.) to it. Proceedings of the Zoological Society of London 1: 57-60.

Bond, M., López, G., Reguero, M.A., Scillato Yané, G.J., and Vucetich, M.G. 1998. Los mamíferos de la Formación Fray Bentos (Edad Mamífero Deseadense, Oligoceno superior?) de las provincias de Corrientes y Entre Ríos. Paleógeno de América del Sur y de la Península Antártica. Asociación Paleontológica Argentina, Publicación Especial 5: 41-50.

Bondesio, P., Laza, J.H., Scillato Yané, G.J., Tonni, E.P., and Vucetich, M.G. 1980. Estado actual del conocimiento de los vertebrados de la Fm. Arroyo Chasicó (Plioceno temprano) de la Prov. de Buenos Aires. II Congreso Argentino de Paleontología y Bioestratigrafía y I Congreso Latinoamericano de Paleontología (Buenos Aires), Actas 3: 85-99.

Bowdich, T.E. 1821. An analysis of the natural classifications of Mammalia for the use of students and travelers. Smith, Paris, $115 \mathrm{p}$.

Brookes, J. 1828. A new genus of the order Rodentia. Transactions of the Linnean Society 16: 96-105.

Burmeister, G. 1866. Lista de los mamíferos fósiles del terreno diluviano. Anales del Museo Público de Buenos Aires 1: 121-232. 
Candela, A.M. 2005. Los roedores del "Mesopotamiense" (Mioceno tardío, Formación Ituzaingó) de la provincia de Entre Ríos (Argentina). In: F.G. Aceñolaza (Ed.), Temas de la Biodiversidad del Litoral fluvial argentino II. INSUGEO, Miscelánea 14: 37-48.

Candela, A.M., and Picasso, M.B.J. 2008. Functional Anatomy of the Limbs of Erethizontidae (Rodentia, Caviomorpha): Indicators of Locomotor Behavior in Miocene Porcupines. Journal of Morphology 269: 552-593.

Cione, A.L., and Tonni, E.P. 1995a. Los estratotipos de los pisos Montehermosense y Chapadmalalense (Plioceno) del esquema cronológico sudamericano. Ameghiniana 32: 369-374.

Cione, A.L., and Tonni, E.P. 1995b. Chronostratigraphy and LandMammal Ages in the Cenozoic of southern South America: principles, practices, and the Uquian problem. Journal of $\mathrm{Pa}$ leontology 69: 135-159.

Cione, A.L., and Tonni, E.P. 1995c. Bioestratigrafía y cronología del Cenozoico superior de la región pampeana. In: M.T. Alberdi, G. Leone, and E.P. Tonni (Eds.), Evolución biológica y climática de la región pampeana durante los últimos cinco millones de años, un ensayo de correlación con el Mediterráneo occidental. Museo Nacional de Ciencias Naturales (Madrid), Monografías 12: 47-74.

Cione, A.L., and Tonni, E.P. 1996. Reassesment of the PliocenePleistocene continental timescale of southern South America. Correlation of the Chapadmalalan with Bolivian sections. Journal of South American Earth Sciences 9: 221-236.

Cione, A.L., and Tonni, E.P. 1999. Biostratigraphy and chronological scale of upper-most Cenozoic in the Pampean area, Argentina. In: E.P. Tonni, and A.L. Cione (Eds.), Quaternary vertebrates of South America. Quaternary of South America and Antarctic Peninsula 3: 23-51.

Cione, A.L., and Tonni, E.P. 2001. Correlation of Pliocene to Holocene southern South American and European vertebratebearing units. Bolletino della Societá Paleontológica Italiana 40: 167-173.

Cione, A.L., Azpelicueta, M., Bond, M., Carlini, A.A., Casciotta, J.R., Cozzuol, M.A., de la Fuente, M., Gasparini, Z., Goin, F.J., Noriega, J., Scillato-Yané, G.J., Soilbelzon, L., Tonni, E.P., Verzi, D., and Vucetich, M.G. 2000. Miocene vertebrates from Entre Ríos Province, eastern Argentina. In: F.G. Aceñolaza, and R. Herbst (Eds.), El Neógeno de Argentina. INSUGEO, Serie Correlación Geológica 14: 191-237.

Croft, D.A., Anaya, F., Auerbach, D., Garzione, C., and Mac Fadden, B.J. 2009. New data on Miocene neotropical provinciality from Cerdas, Bolivia. Journal of Mammalian Evolution 16: 175-198.

Croft, D.A., Chick, J.M.H., and Anaya, F. 2011. New Middle Miocene Caviomorph Rodents from Quebrada Honda, Bolivia. Journal of Mammalian Evolution 18: 245-268.

Desmarest, A.G. 1817. Gerboise première espèce: la grande gerboise Dipus maximus Blainv. Nouveau Dictionnaire d'Histoire Naturelle 13: 117-119.

Flynn, J.J., Croft, D.A., Charrier, R., Hérail, G., and Wyss, A.R. 2002. The first Cenozoic mammal fauna from the chilean Altiplano. Journal of Vertebrate Paleontology 22: 200-206.

Flynn, J.J., Wyss, A.R., Croft, D.A., and Charrier, R. 2003. The Tinguiririca Fauna, Chile: biochronology, paleoecology, biogeography, and a new earliest Oligocene South American Land Mammal 'Age'. Palaeogeography, Palaeoclimatology, Palaeoecology 195: 229-259.

Flynn, J.J., Charrier, R., Croft, D.A., Gans, P.B., Herriott, T.M., Wertheim, J.A., and Wyss, A.R. 2008. Chronologic implications of new Miocene mammals from the Cura-Mallín and Trapa Trapa formations, Laguna del Laja area, south central Chile. Journal of South American Earth Sciences 26: 412-423.
Francis, J.C., and Mones, A. 1965. La presencia de vizcachas [Lagostomus (Lagostomopsis) spicatus (Amegh.)] en la Formación Kiyú, Dto. de San José, R. O. del Uruguay. Revista de la Facultad de Humanidades y Ciencias, Montevideo 22: 155-168.

Francis, J.C., and Mones, A. 1966. Las vizcachas, Lagostomus (Lagostomopsis) euplasius (Amegh.), de la formación Maldonado, departamento de Maldonado, República Oriental del Uruguay. Kraglieviana 1: 101-110.

Francis, J.C., and Mones, A. 1968. Los roedores fósiles del Uruguay. Boletín del Laboratorio de Paleontología de Vertebrados 1: 35-55.

Frenguelli, J. 1928. Observaciones geológicas en la región costanera sur de la Provincia de Buenos Aires. Anales de la Facultad de Ciencias de la Educación, Paraná, 2: 1-145.

Hammer, O., Harper, D.A.T., and Ryan, P.D. 2001. PAST: Paleontological Statistics software package for education and data analysis. Palaeontologia Electronica 4: 1-9.

Ilin, A., and Raiko, T. 2010. Practical approaches to Principal Component Analysis in the presence of missing values. Journal of Machine Learning Research 11: 1957-2000.

Isla, F., Taglioretti, M., and Dondas, A. 2015. Revisión y nuevos aportes sobre la estratigrafía y sedimentología de los acantilados entre Mar de Cobo y Miramar, provincia de Buenos Aires. Revista de la Asociación Geológica Argentina 72: 235-250.

Jackson, J.E., Branch, L.C., and Villareal, D. 1996. Lagostomus maximus. Mammalian Species 543: 1-6.

Kraglievich, L. 1926. Sobre el conducto humeral en las vizcachas y paquirucos chapadmalenses con descripción del Paedotherium imperforatum. Anales del Museo Nacional de Historia Natural, Buenos Aires, 34: 45-88.

Kraglievich, L. 1934. La antigüedad Pliocena de las Faunas de Monte Hermoso y Chapadmalal, deducidas de su comparación con las que le precedieron y sucedieron. El Siglo llustrado, Montevideo, $136 \mathrm{p}$.

Kraglievich, J.L. 1952. El perfil geológico de Chapadmalal y Miramar. Resumen preliminar. Revista del Museo Municipal de Ciencias Naturales y Tradicionales de Mar del Plata 1: 8-37.

Kraglievich, J.L. 1959a. Rectificación acerca de los supuestos "molares humanos fósiles" de Miramar (Prov. de Buenos Aires). Revista del Instituto de Antropología de Rosario 1: 223-236.

Kraglievich, J.L. 1959b. Contribuciones al conocimiento de la geología cuartaria en la Argentina. $4^{\circ}$ Nota acerca de la geología costera en la desembocadura del Arroyo Malacara (Provincia de Buenos Aires). Comunicaciones Museo Argentino de Ciencias Naturales Bernardino Rivadavia, Geología 1, 17: 3-9.

Kramarz, A.G. 2001. Registro de Eoviscaccia (Rodentia, Chinchillidae) en estratos colhuehuapenses de Patagonia, Argentina. Ameghiniana 38: 237-242.

Kramarz, A.G., Garrido, A., Forasiepi, A., Bond, M., and Tambussi, C. 2005. Estratigrafía y vertebrados (Aves y Mammalia) de la Formación Cerro Bandera, Mioceno Temprano de la Provincia del Neuquén, Argentina. Revista Geológica de Chile 32: 273-291.

Kramarz, A.G., Vucetich, M.G., and Arnal, A. 2013. A new Early Miocene chinchilloid hystricognath rodent; an approach to the understanding of the early chinchillid dental evolution. Journal of Mammalian Evolution 20: 249-261.

Marshall, L.G., and Patterson, B. 1981. Geology and geochronology of the mammal-bearing Tertiary of the Valle de Santa María and Río Corral Quemado, Catamarca Province, Argentina. Fieldiana Geology9: 1-80.

Marshall, L., Berta, A., Hoffstetter, R., Pascual, R., Reig, O.A., Bombin, M., and Mones, A. 1984. Mammals and stratigraphy: geochronology of the continental mammal- bearing Quaternary of South America. Palaeovertebrata Mémoire Extraordinaire 1-76. 
Mones, A. 1980. Sobre una colección de vertebrados fósiles de Monte Hermoso (Plioceno superior), Argentina, con la descripción de una nueva especie de Marmosa (Marsupialia: Didelphidae). Comunicaciones Paleontológicas del Museo de Historia Natural de Montevideo 8: 159-169.

Mones, A. 1986. Palaeovertebrata sudamericana. Catálogo sistemático de los vertebrados fósiles de América del Sur. Parte I. Lista preliminar y bibliografía. Courier Forschungsintitut Senckenberg 82: 1-625.

Moreno, F.J.P. 1888. Informe preliminar de los progresos del Museo La Plata durante el primer semestre de 1888, presentado al señor ministro de Obras Públicas de la Provincia de Buenos Aires. Boletín del Museo de La Plata 2: 1-35.

Nasif, N.L., Candela, A., Rasia, L., Madozzo Jaén, M.C., and Bonini, R. 2013. Actualización del conocimiento de los roedores del Mioceno tardío de la Mesopotamia Argentina: aspectos sistemáticos, evolutivos y paleobiogeográficos. In: J.I. Noriega, and D. Brandoni (Eds.), El Neógeno de la Mesopotamia Argentina. Publicación Especial de la Asociación Paleontológica Argentina 14: 153-169.

Ojeda, R., and Bidau, C. 2013. Lagostomus maximus. The IUCN Red List of Threatened Species 2013: e.T11170A22190618. World Wide Web: http://dx.doi.org/10.2305/IUCN.UK.20132.RLTS.T11170A22190618.en.

Ortiz, P.E., Jayat, J.P., Nasif, N.L., Teta, P., and Haber, A. 2012. Roedores del Holoceno tardío de la Puna de Atacama, sitio arqueológico Tebenquiche Chico, Catamarca, Argentina. Archaeofauna 21: 249-266.

Prevosti, F.J., and Pardiñas, U.F.J. 2009. Comment on "The oldest South American Cricetidae (Rodentia) and Mustelidae (Carnivora): Late Miocene faunal turnover in central Argentina and the Great American Biotic Interchange" by D.H. Verzi and C.I. Montalvo (Palaeogeography, Palaeoclimatology, Palaeoecology 267 (2008) 284-291). Palaeogeography, Palaeoclimatology, Palaeoecology 280: 543-547.

Pascual, R. 1966. Vertebrata. In: A.V. Borrello (Ed.), Paleontografía Bonaerense. Buenos Aires: Comisión de Investigaciones Científicas de la Provincia de Buenos Aires, p. 1-202.

Pocock, R.I. 1922. On the external characters of some Hystricomorph Rodents. Proceedings of the Zoological Society of London 92: 365-427.

Rasia, L.L. 2016. [Los Chinchillidae (Rodentia, Caviomorpha) fósiles de la República Argentina: sistemática, historia evolutiva y biogeográfica, significado bioestratigráfico y paleoambiental. Tesis doctoral. Facultad de Ciencias Naturales y Museo, Universidad Nacional de La Plata, La Plata, 381 p. Unpublished.].

Rasia, L.L., and Candela, A.M. 2013. Systematic and biostratigraphic significance of a chinchillid rodent from the Pliocene of eastern Argentina. Acta Palaeontologica Polonica 58: 241-254.

Rasia, L.L., Candela, A.M., and Flores, D.A. 2011. Sexual dimorphism in living and fossil plains viscachas (Rodentia, Caviomorpha, Chinchillidae) of Argentina: a qualitative approach. Ameghiniana 48: 196-197R.

Risso Dominguez, J.D. 1949a. Estratigrafía de las Barrancas de Chapadmalal y Vorohué. Estudios 81: 353-372.

Risso Dominguez, J.D. 1949b. Estratigrafía de las Barrancas de Chapadmalal y Vorohué. Estudios 81: 419-431.

Rovereto, C. 1914. Los estratos araucanos y sus fósiles. Anales del Museo Nacional de Historia Natural de Buenos Aires 25: 1-247.

Schultz, P.H., Zárate, M., Hames, W., Camilión, C., and King, J. 1998. A 3.3 Ma impact in Argentina and possible consequences. Science 282: 2061-2063.
Scott, W.B. 1905. Mammalia of the Santa Cruz Beds. Vol. 5, Paleontology. Part 3, Glires. In: W.B. Scott (Ed.), Reports of the Princeton University Expeditions to Patagonia, 1896-1899. Princeton University, E. Schweizerbart'sche Verlagshandlung (E. Nägele), Stuttgart, p. 384-490.

Taglioretti, M., Miño-Boilini, Á.R., Scaglia, F., and Dondas, A. 2014. Presencia de Proscelidodon patrius (Xenarthra, Scelidotheriinae) en la Formación Chapadmalal (Plioceno Superior), Mar del Plata, Buenos Aires, Argentina: implicancias bioestratigráficas. Ameghiniana 51: 420-427.

Tullberg, T. 1899. Ueber das System der Nagethiere: eine phylogenetische Studie. Nova Acta Regiae Societatis Scientiarium Upsaliensis 3: 1-514.

Verzi, D.H., and Montalvo, C.I. 2008. The oldest South American Cricetidae (Rodentia) and Mustelidae (Carnivora): late Miocene faunal turnover in central Argentina and the Great American Biotic Interchange. Palaeogeography, Palaeoclimatology, Palaeoecology 267: 284-291.

Verzi, D.H., Montalvo, C.I., and Deschamps, C.M. 2008. Biostratigraphy and biochronology of the Late Miocene of central Argentina: evidence from rodents and taphonomy. Geobios 41: 145-155.

Vucetich, M.G. 1984. Los roedores de la Edad Friasense (Mioceno medio) de Patagonia. Revista del Museo de La Plata VIII. Paleontología 50: 47-126.

Vucetich, M.G. 1986. Historia de los Roedores y Primates en Argentina: su aporte al conocimiento de los cambios ambientales durante el Cenozoico. $4^{\circ}$ Congreso Argentino de Paleontología y Bioestratigrafía (Mendoza), Actas 2: 157-165.

Vucetich, M.G. 1989. Rodents (Mammalia) of the Lacayani fauna revisited (Deseadan, Bolivia). Comparison with new Chinchillidae and Cephalomyidae from Argentina. Bulletin du Muséum National d'Histoire Naturelle 11: 233-247.

Vucetich, M.G. 1991. Los roedores de Salla y Lacayani (Bolivia) y su correlación con los de otras faunas de edad Deseadense (Oligoceno). In: R. Suárez-Soruco (Ed.), Fósiles y Facies de Bolivia Vertebrados. Revista Técnica de Yacimientos Petrolíferos Fiscales Bolivianos 12: 625-629.

Vucetich, M.G., and Verzi, D.H. 1995. Los roedores caviomorfos. In: M.T. Alberdi., G. Leone, and E.P. Tonni (Eds.), Evolución Biológica y Climática de la Región Pampeana durante los últimos cinco millones de años. Un ensayo de correlación con el Mediterráneo occidental. Monografías Museo Nacional de Ciencias Naturales de Madrid 12: 213-225.

Vucetich, M.G., Dozo, M.T., Arnal, M., and Pérez, M.E. 2015. New rodents (Mammalia) from the late Oligocene of Cabeza Blanca (Chubut) and the first rodent radiation in Patagonia. Historical Biology: An International Journal of Paleobiology 27: 236-257.

Walton, A.H. 1997. Rodents. In: R.F. Kay, R.H. Madden, R.L. Cifelli, and J.J. Flynn (Eds.), Vertebrate Paleontology in the Neotropics: the Miocene fauna of La Venta, Colombia, Smithsonian Institution Press, Washington D.C. p. 392-409.

Weir, B.J. 1974. The tuco-tuco and plains viscacha. In: I.W. Rowlands, and B.J. Weir (Eds.), The Biology of Hystricomorph Rodents. Symposia of the Zoological Society of London 34: 113-130.

Wiegmann, A.F.A. 1835. Bericht über die Fortschritte der Zoologie im Jahre 1834. Archiv fiir Naturgeschichte 1: 255-348.

Wood, A.E. 1955. A revised classification of the rodents. Journal of Mammalogy 36: 165-187.

Zárate, M.A. 1989. [Estratigrafía y geología del Cenozoico tardío aflorante en los acantilados marinos comprendidos entre Playa San Carlos y el arroyo Chapadmalal, partido de General Pueyrredón, Provincia de Buenos Aires. Tesis Doctoral, Facultad de Ciencias 
Naturales y Museo, Universidad Nacional de La Plata, 221 p. Unpublished.].

Zárate, M.A. 2005. El Cenozoico tardío continental de la Provincia de Buenos Aires. In: R. de Barrio, R. Etcheverry, M. Caballé, and E. Llambías (Eds.), $16^{\circ}$ Congreso Geológico Argentino. Geología y Recursos Minerales de la Provincia de Buenos Aires. (La Plata), Relatorio: 139-158.

\section{Appendix 1}

List of specimens used for comparison and for the PCA.

Lagostomus antiquus (late Miocene): MASP 32 (holotype).

Lagostomus laminosus (late Miocene): MACN-A 8883 (holotype); MACN-Pv 5884

Lagostomus pretrichodactyla (late Miocene): MACN-Pv 8339 (holotype); MACN-Pv 8337; MACN-Pv 8345.

Lagostomus debilis (Pleistocene) MACN-A 1255 (holotype). Lagostomus heterogenidens (Pleistocene): MACN-A 1187 (holotype). Lagostomus minimus (Pleistocene): MACN-A 1098 (holotype). Lagostomus cavifrons (Pleistocene): MACN-A 1651 (holotype). Lagostomus egenus (Pleistocene): MACN-A 417 (holotype).
Lagostomus maximus (recent): MACN-Ma 49.289; MACN-Ma 49.291; MACN-Ma 50.10; MACN-Ma 50.13; MACN-Ma 50.14; MACN-Ma 50.15; MACN-Ma 50.17; MACN-Ma 50.18; MACN-Ma 50.20; MACNMa 50.21; MLP-Mz 14; MLP-Mz 19; MLP-Mz 37; MLP-Mz 38; MLPMz 39; MLP-Mz 41; MLP-Mz 42; MLP-Mz 45; MLP-Mz 54; MLP-Mz 59; MLP-Mz 61; MLP-Mz 64; MLP-Mz 230; MLP-Mz 254; MLP-Mz 269; MLP-Mz 338; MLP-Mz 379; MLP-Mz 565; MLP-Mz 720; MLPMz 1473; MLP-Mz 1602; MLP-Mz 1603; MLP-Mz 1604; MLP-Mz 1605; MLP-Mz 1634; MLP-Mz 1642; MLP-Mz 1651; MLP-Mz 1657; MLP-Mz 1659; MLP-Mz 1728.

doi: 10.5710/AMGH.01.09.2016.3012

Submitted: April 15th, 2016

Accepted: September $1^{\text {st }}, 2016$ 